\title{
Devenir musicien « ordinaire »
}

Construction et entretien des vocations des enseignants de musique classique

Becoming an "ordinary" musician: How the Vocations of Classical Music

Teachers are Constructed and Maintained

Transformarse en un músico « ordinario ». Construcción y mantenimiento de vocaciones de los profesores de música clásica

\section{Adrien Pégourdie}

\section{(2) OpenEdition}

Journals

Édition électronique

URL : http://journals.openedition.org/bssg/108

DOI : $10.4000 /$ bssg. 108

ISSN : 2490-9424

Éditeur

Presses universitaires de Vincennes

Référence électronique

Adrien Pégourdie, «Devenir musicien « ordinaire » », Biens Symboliques / Symbolic Goods [En ligne], 1 । 2017, mis en ligne le 15 octobre 2017, consulté le 04 mars 2021. URL : http://

journals.openedition.org/bssg/108; DOl : https://doi.org/10.4000/bssg.108 

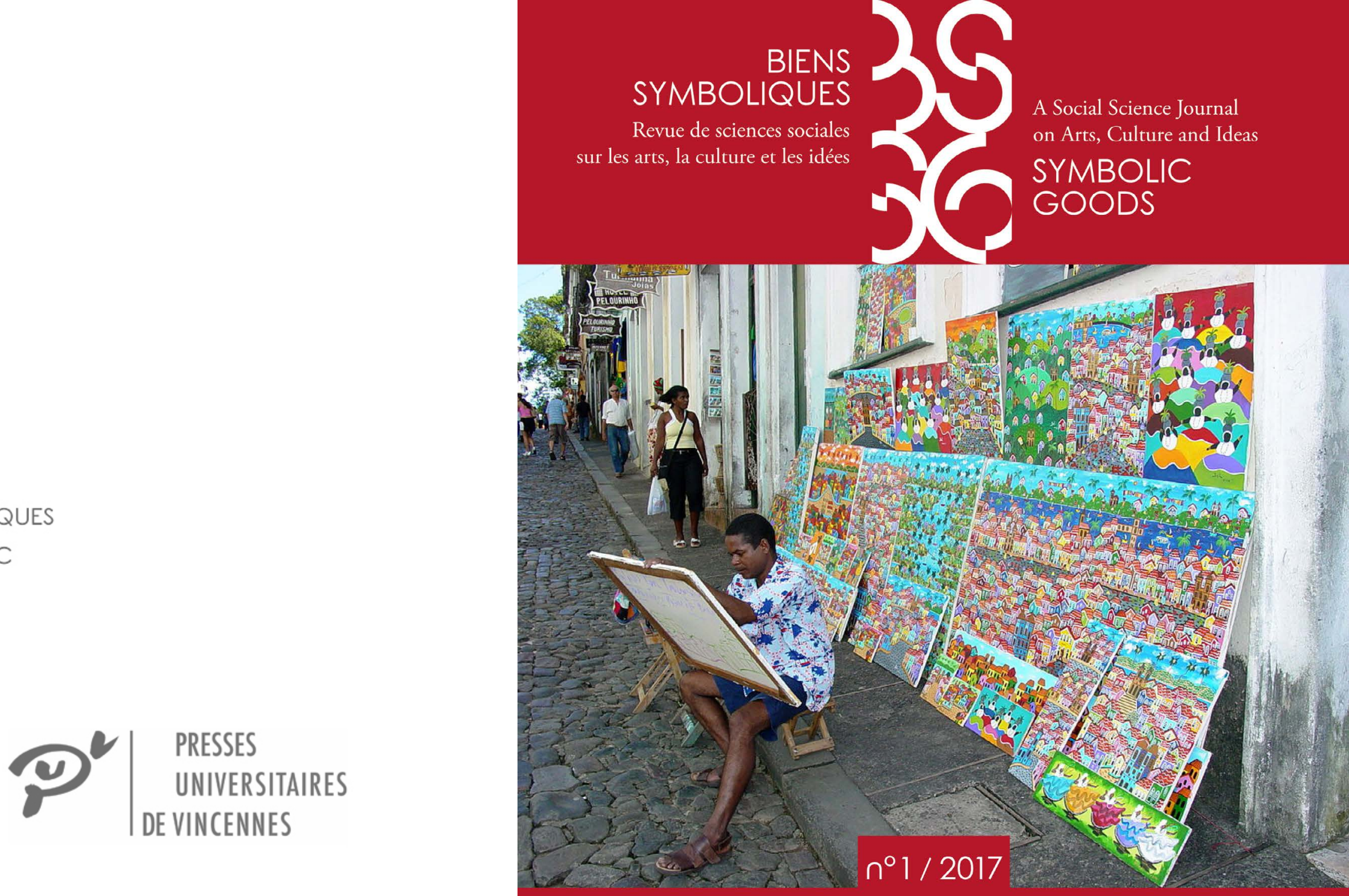

\section{Artistes ordinaires \\ Ordinary Artists}




\author{
Devenir musicien « ordinaire » \\ Construction et entretien des vocations \\ des enseignants de musique classique
}

Becoming an "Ordinary" Musician

How the Vocations of Classical Music

Teachers are Constructed and Maintained

\author{
Adrien Pégourdie \\ traduction | translation \\ Jean-Yves Bart
}

Les métiers artistiques, en cultivant le don de soi au service du désintéressement, constituent des secteurs d'activité spécifiques où le fort investissement personnel implique davantage des rétributions symboliques que matérielles (Sapiro 2007a). La recherche de l'épanouissement spirituel y semble plus déterminante que celle des profits temporels, ce qui fait de l'accès à ces métiers la concrétisation d'une vocation (Menger 2004 ; Kris \& Kurz 1987). Les enseignants de musique classique étudiés dans cet article n'échappent pas à cette tendance ${ }^{1}$. La référence à la vocation est très

1 Cet article s'appuie sur une thèse consacrée aux instrumentistes classiques d'une ville de province française (Pégourdie 2013). L'enquête prend pour terrain quatre institutions musicales : deux conservatoires, un orchestre symphonique et un ensemble baroque. Plusieurs méthodes d'enquête ont été mobilisées. Un volet qualitatif a été mis en place avec la réalisation de 65 entretiens semi-directifs auprès des instrumentistes et de quelques administratifs, auxquels s'ajoute une vingtaine d'observations des cours, des répétitions et des concerts. 88 questionnaires ont également été récoltés auprès des 117 musiciens qui constituent la population, soit un taux de réponse de $75,2 \%$
Artistic occupations' cultivation of a sense of selfless commitment make them sectors of activity in which intense personal engagement yields symbolic rather than material rewards (Sapiro 2007a). The quest for spiritual self-fulfilment appears more important than that for worldly benefits, meaning that accessing such jobs constitutes the realization of a vocation (Menger 2004; Kris \& Kurz 1979). The classical music teachers examined in this paper fall within this category 1. References to vocation frequently come up in the words of these ordinary artists ${ }^{2}$ employed in low-level provincial music

1 This paper is based on $\mathrm{PhD}$ research on classical instrumentalists in a provincial French town (Pégourdie 2013). Fieldwork was conducted at four musical institutions: two conservatories, a symphony orchestra, and a baroque ensemble. The study used a variety of methods. Qualitative methods included 65 semi-directive interviews with instrumentalists and a few administrative staff, as well as around 20 observations of classes, rehearsals, and concerts. I also collected 88 of the 117 questionnaires submitted to musicians in the population $(75.2 \%$ response rate).

2 On the concept of ordinary artist, see the introduction to this issue by Géraldine Bois and Marc Perrenoud. 
présente chez ces artistes « ordinaires "2, employés dans des conservatoires « modestes" (un conservatoire à rayonnement régional - $\mathrm{CRR}$ - et un conservatoire à rayonnement communal - CRC - de province) ${ }^{3}$ et donc éloignés des positions dominantes du champ de la musique classique. Leur devenir professionnel aurait été formulé dès l'enfance et serait la réalisation d'aspirations de jeunesse : «Bon déjà pour moi, c'était évident. Depuis toute petite, je voulais être musicienne professionnelle », " J'ai su très tôt que je ferais de la musique et du violon ».

Si un consensus s'établit donc parmi les musiciens qui se pensent a posteriori « faits pour ça », cette forme de «prédestination » occulte tous les processus sociaux qui contribuent à la genèse et l'intériorisation de ce modèle vocationnel. « Parce qu'il appartient au travail d'inculcation de la vocation d'imposer, en même temps que la vocation, la

2 Sur la notion d'artiste " ordinaire », voir l'introduction de ce numéro rédigée par Géraldine Bois et Marc Perrenoud.

3 L'enseignement musical en France est organisé selon un schéma pyramida hiérarchisant les différentes institutions de formation musicale. Au sommet, figurent les Conservatoires nationaux supérieurs de musique (CNSM) de Paris et de Lyon chargés de former les professionnels de la musique classique. Puis viennent, par ordre décroissant, les conservatoires à rayonnement régional (CRR), les conservatoires à rayonnement départemental (CRD), les conservatoires à rayonnement communal (CRC) et les écoles non agréées, qui sont chargés de former des amateurs plus ou moins avancés. academies (a regional - "CRR" - and a municipal - "CRC"conservatory), far from the leading positions in the classical music field ${ }^{3}$. They report having formulated their professional aspirations at a young age: "It was crystal clear to me; ever since I was small, l'd wanted to be a professional musician;" "I knew that I would play music, play the violin, very early on." While we observe a consensus between musicians who believe they were "made for this" after the fact, this idea of predestination conceals all the social processes contributing to the genesis and internalization of this vocational model. "Because the inculcation process of vocation involves imposing the ignorance of its determining factors at the same time as the vocation itself" (Suaud 1978: 10), this paper sets out to shed light on the mechanisms of the inculcation of vocation in youth.

While this is a central issue which could be applied to all musicians, addressing it is not sufficient to fully understand how vocation works in this population. Considering their condition as ordinary artists, we should also examine how they maintain their vocation in adulthood. Insofar as they have few symbolic rewards due to their inferior position in the music world, we also need to research how they maintain their vocation once they have secured a teaching position.

3 In France, music education is organized in hierarchical pyramid form. On the top, we find the national upper music conservatories (CNSM) of Paris and Lyon, which are in charge of training classical music professionals. Then, in descending order, we have the regional conservatories (CRR), the departmental conservatories (CRD), the municipal conservatories (CRC), and non-accredited schools tasked with training amateurs of varying levels. 
méconnaissance des déterminismes qui la rendent possible » (Suaud $1978: 10$ ), cet article s'attache à percer à jour les mécanismes de ce travail d'inculcation juvénile de la vocation. $\mathrm{Si}$ cette question est essentielle et potentiellement transposable à l'ensemble des musiciens, elle n'épuise néanmoins pas la problématique de la vocation de la population étudiée. Leur condition d'artistes « ordinaires» amène en effet à s'interroger sur l'entretien de la vocation à l'âge adulte. Dans la mesure où ils ne sont parvenus, du fait de l'obtention d'une position reléguée dans l'univers musical, qu'à de faibles rétributions symboliques, il s'agit également de se pencher sur la manière dont leur vocation se maintient une fois leur poste d'enseignant obtenu.

Pour traiter cette double dimension de construction juvénile et d'entretien postérieur de la vocation, nous nous appuierons sur les trois axes d'étude sociologique de la vocation déterminés par Vincent Dubois (2013). Le premier renvoie à l'analyse des logiques sociales de l'orientation professionnelle. II s'agit de comprendre les déterminants sociaux de l'engagement dans la carrière artistique en dépassant les discours empreints d'illusion biographique formulant cet engagement comme un choix ou une évidence. Pour cela, il convient de revenir sur les conditions objectives ainsi que sur les agents et les institutions qui participent à inculquer ce sentiment de «prédestination » chez les jeunes instrumentistes. Cette analyse incite à une réflexion sur les mécanismes de la croyance collective dans le talent des apprentis musiciens.
To study the construction of vocation in youth and its subsequent maintenance, I rely on the three angles of sociological analysis of vocation identified by Vincent Dubois (2016). The first consists in analysing the social logics of professional career paths. Our understanding of the social determinants of engagement in an artistic career should go beyond formulations of such engagement as a choice or a self-evident development, often characterized by biographical illusio. This requires an examination of the objective conditions, agents, and institutions involved in instilling this sense of predestination in young instrumentalists. This analysis yields insight into the mechanisms of collective belief in talent in young musicians.

The second angle of sociological analysis of vocation focuses on the processes of commitment to a selfless relationship to work. Indeed, the revelation of a vocation also involves a conversion process whereby work is experienced as personal self-fulfilment leading to spiritual rewards, requiring young musicians to commit "body and soul" to playing an instrument. This conversion process, resulting in the adoption of ascetic behaviours, can be analysed by combining the social properties and actions of agents and institutions, beginning with family and education. 
Le deuxième axe d'étude sociologique de la vocation se focalise sur les procédés d'adhésion à un rapport désintéressé au travail. La révélation d'une vocation passe en effet également par la mise en place d'un « processus de conversion » faisant du travail un principe d'épanouissement personnel au service de rétributions spirituelles, principe impliquant un engagement «corps et âme » du jeune musicien dans la pratique instrumentale. Ce «processus de conversion », qui s'incarne dans l'adoption de comportements ascétiques, s'analyse par la combinaison de propriétés sociales et de l'action d'agents et d'institutions, en particulier l'environnement familial et le système de formation.

Ces deux axes, à l'origine de la construction des vocations et dont les effets se font ressentir pendant les années de formation du jeune musicien, sont évoqués dans une première partie.

Le troisième axe se concentre sur l'appropriation de croyances quant à l'intérêt pour la collectivité du métier exercé. «Au-delà du travail et des satisfactions personnelles qu'il peut apporter, la vocation se réfère, en troisième lieu, à un horizon qui peut notamment être politique, esthétique ou moral, conduisant à définir les métiers concernés en référence à des valeurs ou des fonctions sociales universelles » (Dubois 2013 : 10). Le flou de la notion d'intérêt pour la collectivité sert ici de base aux processus de maintien de la vocation des enseignants de musique. Plusieurs stratégies de « réassurance vocationnelle » se distinguent alors, allant de la revendication des logiques de « l'art pour l'art » par la valorisation des
These first two features of vocation, which operate in the early stages of the construction of vocation and impact the training years of young musicians, are discussed in the first section of this paper.

The third angle is the study of how beliefs in the collective value of a job are appropriated: "Beyond the work itself and the personal rewards it may bring, vocation involves a reference to a political, aesthetic, or moral horizon; such occupations are defined in reference to universal social values and functions." (Dubois 2016: 2). The fuzziness of this idea of collective value serves as a basis for maintaining the vocation of music teachers. Several strategies of vocational reassurance can be distinguished, from the reference to art for art's sake through engagement in ancillary instrumental activities to its replacement by an emphasis on the ideal of cultural democratization or the educational mission. The 
activités instrumentales annexes, à sa substitution par la mise en avant d'un idéal de démocratisation culturelle ou d'une mission d'encadrement de la jeunesse. Ces différentes stratégies, observées autant dans les discours que dans les manières d'enseigner et de concevoir la pédagogie, sont analysées dans une seconde partie. second section of this paper analyses these strategies, observed in discourse, as well as in ways of teaching and understanding teaching.

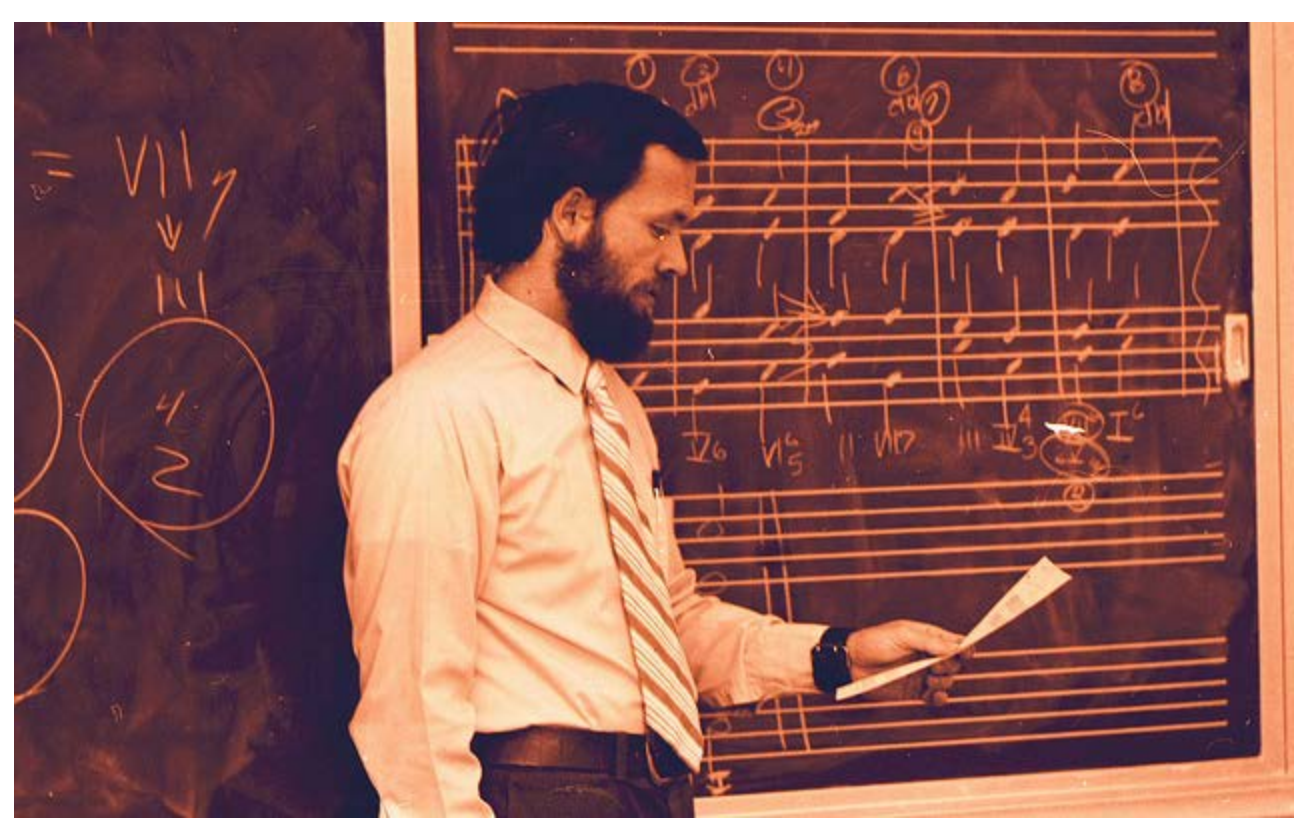

Enseigner la musique Teaching music

(c) Creative Commons

https://www.flickr.com/photos/69125796@N00/7420906168 


\section{La naissance de la vocation}

Métiers à vocation, les professions de la musique classique empruntent aux logiques du « Beruf », conception protestante du métier mêlant « profession » et « vocation » et qui fait du travail un devoir religieux. On y retrouve deux des principes fondamentaux de ce rapport à l'activité professionnelle : la prédestination, appréhendée sous l'aspect du don, et le comportement ascétique (Weber 2000).

\subsection{La croyance dans le don}

Le sentiment quasi mystique d'avoir été « appelé » à cette carrière professionnelle est indissociable chez les musiciens d'une certitude de l'existence d'un don pour la pratique instrumentale. Jacques, trompettiste, fils de cheminot et d'une femme au foyer, invoque cet argumentaire pour commenter sa progression rapide.

" C'est ce qu'on appelle le don. C'est pas pour me gonfler les chevilles, mais c'est ce qu'on appelle le don. Tu m'aurais donné un crayon avec une feuille blanche, j'aurais été incapable de faire du dessin. Même en prenant des cours particuliers cinq heures par jour, je serais incapable de dessiner quelque chose. Si j'avais fait du violon peutêtre que ça aurait pas bien marché. Bon il se trouve que la trompette, ca a marché. Donc j'étais quelqu'un de doué. Et ça a été très vite. »

Le recours à l'innéité des capacités est ainsi fréquent dans les discours des musiciens. Ce sentiment d'élection conforte la logique de la prédestination qui s'impose dans l'univers indigène comme principe explicatif des possibilités d'accès

\section{The birth of vocation}

Occupations in classical music are vocational and informed by the rationale of Beruf, a Protestant conception of an occupation that combines profession and vocation and equates work with religious duty. Two basic principles of this relationship to professional activity are found in our case: predestination, envisioned in terms of a gift, and ascetic behaviour (Weber 2010).

\subsection{Belief in the gift}

For musicians, the virtually mystical sense of having been "called" to pursue their career comes with the certainty of having a gift for playing an instrument. Jacques, a trumpet player, son of a rail worker and a stay-at-home mother, invokes this argument as he comments on his rapid progression:

\footnotetext{
"That's what they call a gift. Not to get big-headed, but that's what they call a gift. If you'd given me a pencil and a blank sheet of paper, l'd have been incapable of drawing. Even if I took five hours of private lessons every day, I'd still be incapable of drawing anything. If I had taken up the violin, maybe it wouldn't have worked out so well. As it happens, the trumpet worked out. So I was a gifted person, and things went very fast."
}

Musicians frequently make such references to innate skills. This sense of having been chosen reinforces the logic of predestination that prevails in the music world as the explanation for opportunities to access professionalization. 
à la professionnalisation. La croyance en des qualités naturelles exceptionnelles vient alors entretenir et renforcer la vocation. Se percevant comme un «élu » au talent singulier, l'instrumentiste est persuadé de l'évidence de son destin musical et d'avoir autant choisi la musique qu'il a été choisi

par elle 4 .

Cette thématique du talent conduit à plusieurs interrogations sociologiques. Par un impératif disciplinaire qui impose de mettre à distance les raisonnements naturalistes (Durkheim 1988), le sociologue se doit de déterminer les processus de construction sociale qui aboutissent à l'émergence de ce qui est considéré comme le talent. Celui-ci, loin de survenir “ comme par enchantement », ne peut se donner à voir que dans des conditions sociales particulières permettant l'activation de dispositions à la pratique instrumentale. Reste cependant à s'interroger sur ce que désigne la notion même de talent musical. Ce questionnement se révèle extrêmement problématique pour les sociologues qui ont tenté d'y répondre. Faute d'un étalon universel et unanimement reconnu qui permettrait de déterminer des hiérarchies « objectives » de l'interprétation ou de la création musicale, l'objectivation et la quantification du talent ou du « génie » artistique a toujours été en proie à des limites indépassables (Menger 2002).

L'impossibilité d'une mesure ou d'une comparaison du talent ne constitue toutefois pas un frein à l'étude sociologique. En effet, ce qui est intéressant pour l'analyse n'est pas la

4 Ce sentiment n'est pas exclusif des instrumentistes mais se rencontre dans la majorité des professions « à vocation ». II est ainsi relevé par Nicolas Lefèvre (2010) dans le cas des cyclistes.
Belief in exceptional, natural qualities maintains and strengthens vocations. Perceiving themselves as "chosen ones," with a unique talent, instrumentalists are persuaded that their musical destiny is inevitable and that music has chosen them just as much as they have chosen it ${ }^{4}$.

This emphasis on talent suggests several lines of sociological questioning. In light of the disciplinary imperative which promotes a certain distance from naturalistic arguments (Durkheim 1982), sociologists must determine the social construction processes leading to the emergence of what is considered to be talent. Talent does not appear magically, but only in specific social conditions conducive to activating dispositions for playing an instrument. Additionally, the very definition of musical talent has proved extremely problematic for sociologists who have examined the concept. For lack of a universal, unanimously recognized yardstick allowing the determination of objective hierarchies of musical performance and creation, objectifying and quantifying artistic talent or "genius" has always led to a dead-end (Menger 2002).

However, the impossibility of measuring or comparing talent does not constitute a hindrance to sociological analysis. Sociology is not concerned with establishing whether or not talent exists, or with comparing the respective talents of

4 This feeling is not exclusive to instrumentalists, being found in the majority of the so-called vocational occupations, such as cycling (Lefèvre 2010). 
détermination de l'existence ou non d'un talent, ou une vaine comparaison du volume de talent de chaque instrumentiste, mais plutôt le processus par lequel un talent est reconnu à un musicien et par lequel le musicien se reconnaît du talent. II en est, en fait, de la notion de talent comme de la notion de charisme conceptualisée par Max Weber (1995). Le talent, comme le charisme, relève d'une croyance, partagée par celui qui le possède et par ceux qui le reconnaissent, en l'exceptionnalité des qualités d'une personne. II constitue une propriété relationnelle qui ne trouve à s'activer que lorsqu'elle est reconnue par des agents extérieurs à l'individu. Ce qui compte alors n'est pas la validité « réelle » du talent ou du charisme, mais le procédé par lequel s'instaure la croyance collective en cette qualité.

Étudier le concept de talent ou de don musical implique donc d'analyser la construction sociale de la croyance partagée dans le talent. Ce sont les mécanismes sociaux par lesquels un don est reconnu à l'instrumentiste et par lesquels celuici se persuade de la réalité de son talent que nous allons maintenant mettre au jour.

\subsubsection{L’héritage familial}

La compréhension des logiques sociales de construction du don implique une réflexion concernant les inégalités initiales d'héritage musical. La plus ou moins grande proximité de la famille à l'univers musical est un élément fondamental des modalités de production du talent de l'instrumentiste (Augustins 1991). En effet, appartenir à une famille d'amateurs instrumentalists. Rather, its task is to examine the process leading to the recognition of talent in musicians by themselves and others. Like the concept of charisma conceptualized by Max Weber (2013), talent is based on a belief in the exceptional nature of a person's qualities, shared by that person and those who recognize such talent in them. It is a relational property that is only activated when recognized by agents other than the individual. What matters in that sense is not the actual validity of talent or charisma, but the process through which collective belief in that quality works.

Studying the concept of musical talent or gift thus requires us to look into the social construction of shared belief in talent. This section evidences the social mechanisms of the external and internal recognition of the instrumentalist's gift.

\subsubsection{Family legacy}

Understanding the social logics of the construction of gifts requires us to ponder initial inequalities in musical legacy. The family's varying proximity to the music world is a key factor in the modalities of production of the instrumentalist's talent (Augustins 1991). Indeed, belonging to a family of amateur or, even more so, professional musicians induces a socialization 
et plus encore de professionnels induit une socialisation dès la plus tendre enfance à l'écoute et à la pratique musicale. Cette initiation précoce contribue à occulter le processus d'apprentissage et à envisager la musique comme une " pratique naturelle », dont on ne parvient d'ailleurs pas à dater les débuts. C'est ce qu'atteste le cas de Jeanne, violoncelliste et fille d'une pianiste professionnelle.

« II faut dire que j'ai commencé la musique parce que je suis née dans la musique. J'ai failli naître dans la classe de piano de ma mère donc je suis née dans la musique. J'ai été bercée in utero et après, tout le temps. À l'époque, il y avait pas de congé maternité, elle m'allaitait entre deux élèves. Alors vraiment, j'ai été baignée dans la musique depuis ma plus tendre enfance. Et naturellement, le violoncelle, ça venait tout seul. Je devais être relativement douée parce que je fichais rien et ça avançait tout seul. [...] » AP.-Etvous, vousavezcommencéàquelâgealorslamusique? J. - Alors ça, je n'en sais rien. Trop petite. J'ai commencé le solfège et le piano toute petite avec ma mère. [...] Je crois que dès que j'ai eu un doigt assez fort pour toucher le piano, j'ai commencé le piano. [...] Mais je savais clé de sol, clé de fa toute petite. Je ne me souviens même pas. À cinq ans, je savais mes clés. Donc je ne sais pas quand j'ai commencé.

C'est venu naturellement.

Outre ce « rapport naturel » entretenu avec la pratique instrumentale, la socialisation juvénile permet l'activation précoce des dispositions. Sensibilisé dès sa prime enfance à la musique, le jeune héritier possède une maîtrise technique logiquement supérieure à celle de ses camarades. Offrant le spectacle d'un jeune musicien à l'apparente facilité dans le maniement de l'instrument et interprétant des œuvres in listening to and practice of music from infancy. This early initiation contributes to masking the learning process: music is seen as a "natural practice," and practitioners often struggle to say when they began, such as in the case of Jeanne, a cellist whose mother is professional pianist.

"I have to say, I took up music because I was born into music. I was almost born in my mother's music class, so I was born into music. I was basked in music in the womb and afterwards, all the time. At the time, there was no maternity leave, she would breastfeed me in between two students. So I was really immersed in music from my earliest childhood days. And naturally, the cello came very easily. I must have been fairly gifted, because I wasn't doing any work and things would progress on their own... AP. - So at what age did you take up music yourself? - Well, I have no idea. Too young. I started music theory and piano with my mother when I was very small. [...] I think that as soon as I had a finger that was strong enough to touch the piano, I took up the piano. [...] But I knew the key of $G$ and the key of $F$ when I was really small. By the age of five, I knew all the keys. So I don't know when I began. It came naturally."

In addition to this "natural" relationship to playing an instrument, socialization in childhood enables the early activation of dispositions. Having developed a very early awareness of music, young inheritors logically have a technical mastery that far exceeds that of their peers. Projecting the image of young musicians for whom it is apparently easy to handle their instrument and perform pieces that are inaccessible to other 
inaccessibles aux autres enfants de sa classe d'âge, l'héritier semble démontrer des qualités exceptionnelles pour la musique. II vient alors se conformer à une image idéalisée largement relayée dans l'univers de la musique classique : le jeune prodige. Cette figure mythifiée, qui a pour idéaltype la référence au jeune Mozart ${ }^{5}$, fait de la précocité un facteur de détermination du talent. Cette conformation à une représentation diffusée à l'intérieur de la sphère musicale participe au maintien d'une vision naturaliste du don et l'occultation des déterminants sociaux du talent des héritiers.

L'héritage familial constitue donc un élément fondamental de la construction sociale du talent. Les familles musiciennes, en favorisant l'incorporation juvénile des règles musicales, conduisent l'enfant à développer un « sens pratique » de la pratique instrumentale. Ce « sens pratique » est tellement intégré qu'il masque le processus d'acquisition et apparaît sous les dehors de l'innéité (quel'on retrouve dans l'expression plusieurs fois entendue au cours des entretiens «c'est dans les gènes »).

Mais les familles musiciennes ne se contentent pas de transmettre les conditions sociales de production du talent, elles opèrent également comme les premières instances de légitimation de celui-ci. Le jugement des parents n'est pas qu'affectif, il est aussi, dans ce cas, le jugement d'individus

5 Fils d'un musicien, Mozart représente l'archétype du jeune virtuose capable dès l'âge de six ans de se produire lors d'une tournée internationale avec son père et sa sœur. Pour une analyse sociologique de la vie de Mozart, voir Elias (1991) children in their age group, inheritors appear to showcase exceptional musical skill. They conform to an idealized image that has been widely promoted in the classical music worldthat of the child prodigy. This mythical figure, best embodied by the young Mozart ${ }^{5}$, depicts precocity as a determining factor of talent. Conforming to this representation conveyed within the musical sphere, these young musicians are presented in a way that contributes to upholding a naturalistic vision of gift and to concealing the social factors involved in the talent of inheritors.

Family legacy thus constitutes a crucial element in the social construction of talent. By promoting the bodily internalization of the rules of music, musical families lead the child to develop a "practical sense" of playing an instrument. This practical sense is internalized to a degree that it obscures the learning process and appears under the guise of innateness (expressed by a phrase I heard on several occasions in interviews: "It runs in the genes").

But musical families do not only pass on the social conditions for producing talent; they also operate as the first sites of its legitimization. Parental judgment is not merely sentimental; it is in this case also the judgment of individuals considered to be musically legitimate. The qualities that are praised within the family sphere can thus in part be transposed to the musical

5 The son of a musician, Mozart is the archetypal child virtuoso. He was able to perform alongside his father and sister during an international tour at the age of six. For a sociological analysis of Mozart's life, see Elias (1993). 
considérés comme légitimes musicalement. Les qualités célébrées au sein de la sphère familiale peuvent donc être, en partie, transposées dans la sphère musicale. On peut bien évidemment discuter de la nature objective du jugement parental. Toutefois ce qui importe n'est pas de savoir si les parents sont objectifs ou non, mais de prendre la mesure des effets sur l'enfant de l'opinion prétendument objective des parents concernant son talent. Pour celui-ci, le jugement parental ne saurait être contesté. De ce fait, la reconnaissance familiale du talent contribue à ancrer dans son esprit, de façon très précoce, la certitude de ses qualités innées. L'adoubement parental officie alors comme confirmation de son élection. De cette certitude précoce découle un sentiment de prédestination et une vocation qui apparaissent dès les plus jeunes années du musicien héritier.

La famille n'est cependant pas la seule instance de production de la croyance dans le don. La reconnaissance du talent est également construite au sein des institutions de formation musicale.

\subsubsection{Le rôle des institutions de formation}

Comme le souligne Thomas Morinière (2007: 73), « le don peut être reconnu par une institution (scolaire, artistique, marchande), qui dispose elle-même d'une certaine quantité de capital symbolique à prêter, ce qui détermine la légitimité de l'opération de certification et ses chances de produire la croyance en la valeur du don. " Dans le cas des institutions musicales, la production de la croyance dansle don réside dans l'organisation même du cursus d'études. Le futur professionnel sphere. Of course, the objective nature of parental judgment can be debated. However, what matters is not to establish whether parents are objective or not, but to assess the effects of the so-called objective opinion of parents regarding their children's talent on the children themselves. The children of musicians tend to believe their parents' opinion cannot be challenged. For that reason, the recognition of talent in the family contributes to making them internalize at a very young age the certainty that they have innate qualities. The parental stance acts as a confirmation of their having been chosen. This initial certainty results in a sense of predestination and vocation appearing in the early years of musical inheritors.

Family, it must be said, is not the only site of production of belief in the gift. The recognition of talent is also constructed within music education institutions.

\subsubsection{The role of music training institutions}

Thomas Morinière (2007: 73) noted that "a gift can be recognized by an institution (educational, artistic, or marketoriented) that has at its disposal a certain amount of symbolic capital to loan out, which determines the legitimacy of the operation of certification and its chances of producing belief in the value of the gift." Where musical institutions are concerned, the production of belief in the gift resides in the very organization of the curriculum. As students progress 
a ainsi, au fur et à mesure de son avancée dans la formation, été soumis à diverses modalités de sélection aboutissant à le distinguer du reste de ses camarades. Les examens annuels sanctionnant le passage au niveau supérieur, les auditions de classe qui permettent une comparaison en actes des performances de chacun ${ }^{6}$, ainsi que la décision institutionnelle de l'orientation en fin de second cycle dans la filière professionnelle sont autant des moments d'évaluation que de sélection. Chacun de ces moments peut être assimilé à un rite de passage tendant à consacrer et à légitimer ceux qui le réussissent. Les succès dans les étapes successives « d'écrémage » agissent alors sur l'apprenti musicien comme un signe d'élection. Pour les instrumentistes issus d'un milieu musical, ces réussites confortent la certitude de leur talent ; pour les autres, ces succès répétés représentent autant de preuves qui, en s'accumulant, les convertissent progressivement à la croyance en leur don.

II serait néanmoins réducteur de ne penser l'incorporation de la croyance dans le don que sous l'angle de l'organisation du cursus d'études. Elle prend également une tournure plus individuelle par l'instauration de relations privilégiées entre l'élève et ses professeurs. À la reconnaissance institutionnelle du don, s'ajoute une reconnaissance informelle établie par le corps professoral ${ }^{7}$. En décernant des félicitations et des messages d'encouragement, qui apparaissent aux yeux

6 On peut comparer les auditions avec l'entraînement des athlètes qui agit également comme un lieu de différenciation par la comparaison des niveaux de chaque coureur (Schotté 2012).

7 Nicolas Lefèvre (2010) relève un procédé similaire dans la relation des apprentis cyclistes à leurs entraîneurs. through their curriculum, their professional future is subject to various forms of selection which aim to distinguish them from the rest of their peers. The annual exams granting access to the upper levels, the class auditions allowing the practical comparison of student performances ${ }^{6}$, and the institutional decision to direct students towards specialized courses at the end of high school are opportunities for evaluation and selection. Each of those junctures acts as a rite of passage conferring legitimacy and recognition on students who make it to the next step. Aspiring musicians may then see success in these screening stages as a sign of having been chosen. For the instrumentalists who come from a musical background, these successes reinforce their certainty about their talent; for the others, they work as mounting evidence which progressively brings them round to belief in their gift.

The internalization of belief does not, however, solely operate through the organization of the curriculum. It also has a more individual dimension, as special relationships develop between students and their teachers. The informal recognition of the teaching body adds up to the institutional recognition of the gift $^{7}$. By praising and encouraging them, teachers contribute to building up belief in their students' individual qualities.

6 Auditions can be likened to training for athletes, which also acts as a site of differentiation through the comparison of runners' respective performances (Schotté 2012).

7 Nicolas Lefèvre (2010) observed a similar process in his examination of the relationships between young cyclists and their trainers. 
du jeune élève comme autant de signes de confirmation, les professeurs contribuent à construire chez celui-ci une croyance en ses qualités individuelles.

Le jugement des pédagogues se révèle particulièrement important pour les apprentis musiciens non héritiers. Pour ces derniers, qui ne peuvent trouver dans leur environnement familial d'individus aptes à attester de l'existence de leur talent, l'opinion des enseignants constitue la première manifestation d'une croyance en leur don. L'évaluation des capacités instrumentales par le professeur agit comme une sorte de révélation de leurs qualités musicales instillant, dans leur esprit, la possibilité d'un devenir professionnel. Catalyseur des aspirations et de la vocation, la rencontre avec le premier enseignant ayant « détecté » le potentiel de l'apprenti musicien est alors présentée comme un moment décisif ayant conditionné leur trajectoire sociale et professionnelle. Considérant ce professeur comme leur mentor, ils n'ont pas de mots assez élogieux pour le décrire et caractériser la relation qui les unissait : «Et je le disais tout à l'heure, effectivement j'ai eu la chance de tomber sur un être exceptionnel, un hautboïste exceptionnel, un prof exceptionnel. ».

La croyance dans le don est ainsi un processus de reconnaissance collective qui s'enracine au sein de deux instances : la famille et les établissements de formation musicale. Toutefois ce processus prend des formes différentes en fonction du degré de sensibilisation musicale de la famille du futur musicien. Seuls les héritiers peuvent bénéficier d'une reconnaissance de leur talent au sein de la sphère familiale.
The judgment of teachers is particularly important to the noninheritors among the young musicians. As they cannot find individuals with the legitimacy to confirm the existence of their talent in their family circles, for them the opinion of teachers constitutes the first manifestation of a belief in their gift. The teacher's evaluation of their instrumental skills acts as a revelation of their musical skills, sowing the seed of belief that they have a professional future. The encounter with the first teacher to have detected potential in the young musician acts as a catalyst for aspirations and vocation, and is subsequently presented as a decisive instant which conditioned their social and professional career. They consider that teacher as their mentor, and struggle to find words complimentary enough to describe them and characterize their relationship: "As I was saying earlier, I was lucky enough to cross paths with an exceptional human being, an exceptional oboe player, an exceptional teacher."

Belief in the gift is a process of collective recognition that unfolds in two sites: in the family and at music education institutions. However, the process takes on different forms depending on the degree of musical awareness of the future musician's family. Only inheritors can enjoy recognition of their talent within the family sphere. To them, institutional recognition is a confirmation of their parents' judgment. As 
La reconnaissance institutionnelle agit, pour eux, comme une confirmation du jugement parental. Nés dans la musique et consacrés précocement, ils envisagent également très tôt un devenir professionnel qui apparaît comme une orientation naturelle. À l'inverse, les instrumentistes issus d'un milieu éloigné du monde musical sont dépendants de la reconnaissance établie au sein des conservatoires. Leur sentiment d'élection provient de la structuration du cursus d'enseignement et du jugement du corps professoral. La croyance dans leur don, et par là leur vocation, résulte d'une conversion progressive orchestrée par l'institution ${ }^{8}$.

\subsection{Le comportement ascétique}

La conviction du don n'est cependant pas suffisante pour déterminer, chez le jeune instrumentiste, la naissance d'une vocation. Pour que l'instrumentiste soit en mesure de s'approprier un discours vocationnel, la croyance en des qualités individuelles est nécessaire, mais doit être conjuguée à un engagement sans réserve dans l'activité musicale. En effet, comme le souligne Charles Suaud (1974:75), la vocation constitue la « réalisation d'un destin d'exception, fondé sur la reconnaissance d'aptitudes individuelles et réclamant un investissement total de l'individu ". Cette définition est d'ailleurs revendiquée par les instrumentistes de notre échantillon. Tous affirment que l'engagement « corps et âme » dans la pratique instrumentale est indispensable pour accéder à la professionnalisation et donc consacrer

8 Ce modèle d'incorporation de la vocation par l'action institutionnelle se rencontre également chez les enfants d'agriculteurs admis au petit séminaire (Suaud 1978). they were born into music and, so to speak, notified of their talent at a very young age, they can project themselves into a professional future that appears to them as the natural course of things at a very early stage. Conversely, instrumentalists whose backgrounds are far removed from the music world are dependent on recognition in the conservatories. They derive their sense of being chosen from the structure of the curriculum and the judgment of their teachers. Belief in their gift, and subsequently in their vocation, results from a progressive conversion orchestrated by the institution ${ }^{8}$.

\subsection{Ascetic behaviour}

However, belief in the gift is not sufficient to determine the birth of a vocation in a young instrumentalist. For the instrumentalist to be in a position to appropriate vocational discourse, belief in individual skills is needed; but it must be combined with boundless commitment to the musical activity. Indeed, as Charles Suaud puts it (1974: 75), vocation is the "realization of an exceptional destiny, founded on the recognition of individual abilities and requiring the individual's total commitment." It should be noted that the instrumentalists in my sample actively subscribe to this definition. All claim that committing one's "body and soul" to playing an instrument is indispensable to accessing professionalization, and by doing so confirm their vocation. Gift is a necessary condition but not a sufficient one ${ }^{9}$; it needs to come with a work ethic to

8 This model of internalization of vocation is also found in the children of farmers enrolled in seminaries (Suaud 1978).

9 As Gérard Mauger noted in the post-defence report of my thesis: "Without belief in talent, work cannot be enough to validate belief." 
la vocation. Le don est une condition nécessaire mais pas suffisante $^{9}$, il faut lui adjoindre une éthique de travail sans laquelle le talent ne saurait s'exprimer ${ }^{10}$, comme le souligne Marie, flûtiste, fille d'un employé de banque et d'une éducatrice

spécialisée.

" Je pense qu'il faut au départ avoir des facilités. Mais après, il faut vraiment aussi pouvoir travailler, avoir la capacité de travailler beaucoup. Moi, j'ai souvent vu des cas d'enfants qui étaient au départ moins doués que d'autres, mais qui, par le travail, par l'acharnement, ont réussi à obtenir des diplômes et même pour certains à faire des carrières. Et inversement, des élèves qui avaient plus de facilités et qui se sont reposés dessus, qui n'ont pas progressé et qui se sont faits dépasser par des enfants plus travailleurs. "

\subsubsection{Les formes juvéniles de l'ascèse}

Cette éthique de travail s'incarne dans l'adoption de comportements ascétiques qui s'ancrent pendant la formation musicale. Le jeune musicien doit se soumettre à un travail quotidien de son instrument, dont la durée minimale augmente avec l'avancée dans le cursus. Les vingt minutes journalières préconisées aux débutants se changent rapidement en une heure lorsque l'élève atteint le second cycle (souvent vers l'âge de 10 ans), puis une heure trente, voire deux heures à l'adolescence. La contrainte imposée par ce travail quotidien

9 En effet, comme me l'a fait remarquer Gérard Mauger dans le rapport de soutenance de la thèse : "Sans croyance au talent, le travail ne saurait suffire à valider la croyance. »

10 On remarque ici comment les musiciens s'éloignent largement du mythe de l'artiste romantique bohème qui dénie le travail pour valoriser le talent ou l'inspiration (Heinich 2005). allow talent to express itself ${ }^{10}$-as explained here by Mary, a flautist, the daughter of a bank employee and a special needs teacher:

"I think you need to have a certain aptitude to begin with. But then, you have to be able to really work at it, to have the ability to work a lot. I have often seen cases of children who were initially less gifted than others, but who managed to get degrees and sometimes make careers by working tirelessly. On the other hand, I've seen students who had greater aptitude but who rested on their laurels; they didn't progress and they had more hardworking students do better than they did."

\subsubsection{Youthful forms of asceticism}

This work ethic materializes with the adoption of ascetic behaviours that take root during music education. Young musicians practise their instrument on a daily basis; the minimum duration of this practice increases with time and level. The daily twenty minutes recommended to beginners soon become an hour when students reach secondary school (often around the age of ten), and then an hour and a half to two hours in adolescence. The constraints imposed by such daily practice are sometimes detrimental to the sociability of adolescent musicians, as Franck, a cellist and the son of two bakers, relates:

10 In this sense, musicians are largely at odds with the myth of the bohemian romantic artist who values talent or inspiration over work (Heinich 2005) 
entre alors parfois en contradiction avec la sociabilité amicale du jeune musicien adolescent, comme le souligne Franck, violoncelliste, fils de boulangers.

"Malgré tout, on a été habitué à une certaine rigueur. II ne faut pas se leurrer, c'était quand même un peu dur de travailler pendant que les copains étaient en train de jouer. [...] J'allais jouer un moment et puis j'entendais : "Franck !" Alors, mes copains, ils me chambraient, ils me disaient "Eh Franck, ton violoncelle !". Donc ça faisait un peu rire les copains. »

Consacrant un temps de plus en plus important à l'étude de son instrument, le jeune musicien s'éloigne progressivement du réseau de relations amicales tissées hors de la sphère musicale d'autant plus qu'il est placé dans une section spécifique au sein du cadre scolaire, les classes à horaires aménagés musique (CHAM) ${ }^{11}$. Son travail le coupe également progressivement de ses amitiés antérieures, les week-ends et une partie des vacances étant également dédiés à la musique. L'intensification de la pratique instrumentale conduit donc le jeune musicien à un retrait progressif du monde profane et à un renoncement aux « plaisirs » de la sociabilité adolescente dont témoigne Louis, violoniste, fils d'un militaire et d'une femme au foyer.

" Et quand on est seul dans sa chambre, on a une imagination qui va travailler. Et passer quinze jours de vacances de Pâques à faire que du violon huit heures par

11 Les CHAM sont des classes spécifiques de l'enseignement primaire et secondaire français qui permettent à leurs élèves d'étudier la musique plusieurs après-midis par semaine dans les conservatoires.
"Anyway, we were used to a fairly rigorous schedule. Make no mistake, it was a bit hard to work while my mates were out playing ... I'd go and play for a while and then I'd hear: 'Franck!' So my mates would take the piss, they'd say: 'Hey, Franck, what about your cello!' So they made fun of it a little."

As they devote more and more time to their instrument, young musicians progressively drift away from their friends outside of the music sphere, especially since they follow a distinct curriculum with an adapted schedule at school (CHAM) 11. Work also cuts them off from their older friendships, as they have to spend weekends and some of their holidays working on music. The intensification of music practice leads young musicians to increasingly remove themselves from the profane world and give up the "pleasures" of teenage sociability - in the words of Louis, a violin player and the son of a serviceman and a stay-at-home mother:

"When you're all alone in your room, your imagination starts to work. And spending two weeks of the Easter holidays

11 CHAM-literally classes with schedules adapted for music educationallow students in French primary and secondary schools to study music in conservatories several afternoons each week. 
jour, il est vrai que c'est nettement plus intéressant que d'aller en plein air. »

La valeur ascétique s'exprime également dans la nature même du travail personnel. D'abord car le travail est source d'une souffrance physique chez le musicien. Les douleurs lombaires, les crampes dans les bras, l'engourdissement des doigts, les maux de tête sont autant de manifestations de l'effort important causé par un travail acharné. L'intensité du travail quotidien des jeunes musiciens constitue ainsi une forme de socialisation à l'effort et à la souffrance (Alford \& Szanto 1995) ${ }^{12}$. Mais le labeur quotidien de l'apprenti musicien n'est pas seulement intensif, il est également aride et répétitif. L'élève doit se soumettre tous les jours à un certain nombre d'exercices imposés, réguliers et fastidieux. L'exemple type de la litanie du travail quotidien s'incarne dans l'étude des gammes. Le travail des gammes, qui consiste à répéter à de nombreuses reprises une phrase musicale en respectant les doigtés imposés, constitue ainsi un passage obligé et quotidien qui accompagne l'apprenti musicien durant toute la durée de sa formation. À l'instar de l'apprenti boxeur autorisé à monter sur le ring après avoir multiplié les exercices répétitifs et solitaires (Wacquant 2002), le jeune musicien doit se soumettre à un travail ascétique avant d'atteindre la récompense que constitue l'interprétation d'une œuvre.

12 Sylvia Faure (2000) fait un constat similaire chez les apprentis danseurs classiques, tandis que Pierre-Emmanuel Sorignet (2012) relève que les danseurs contemporains sont davantage à l'écoute des manifestations de souffrance physique. playing violin eight hours a day really is more interesting than going outside."

This ascetic quality is also expressed in the very nature of the musicians' personal work. First, the work causes them physical suffering: back pain, arm cramps, numb fingers, and headaches are routine manifestations of the strain resulting from such hard work. In this sense, the intensity of the daily work of young musicians constitutes a form of socialization in effort and suffering (Alford \& Szanto 1995) ${ }^{12}$. This daily labour is not only intensive, it is also dull and repetitive. Every day, students must subject themselves to a number of regularly scheduled, painstaking exercises. A typical example of the litany of everyday work is scales practice, which consists in repeating a musical phrase many times using the required fingerings - an unavoidable staple of any musician's routine throughout their entire education. Like boxers who are training and only authorized to enter the ring after having performed many repetitive, solitary drills (Wacquant 2003), young musicians must submit to this ascetic work before achieving the reward of being allowed to perform a piece.

12 Sylvia Faure (2000) makes a similar observation in her study of young classical dancers; whereas Pierre-Emmanuel Sorignet (2012) notes that contemporary dancers pay more attention to manifestations of physical pain. 
Pour comprendre la nécessité de ce caractère répétitif et austère du travail, il convient de ne pas occulter que l'apprentissage instrumental est, avant toute chose, un travail d'incorporation d'un savoir faire pratique ${ }^{13}$. La maîtrise technique de l'instrument passe immanquablement par une maîtrise du corps dans l'action ${ }^{14}$. Cette maîtrise corporelle, qui amène le musicien à produire instantanément et quasi mécaniquement une réponse adaptée à une difficulté instrumentale, s'acquiert par des exercices répétitifs et imposés, qui permettent progressivement de façonner et d'éduquer le corps aux exigences de la pratique instrumentale. Ainsi l'étude des gammes a pour objectif principal d'ancrer corporellement, par la répétition, les doigtés adaptés à chaque situation, ce qui conduit, comme le souligne Bourdieu (1972 : 196), à « substituer à un corps sauvage [...] un corps "habitué", c'est-à-dire temporellement structuré ".

L'investissement total du jeune musicien dans la pratique instrumentale, mesuré par le volume de travail personnel auquel il s'astreint, s'incarne donc dans des comportements ascétiques. La coupure avec le monde profane, le dépassement de la souffrance physique et l'apprentissage par répétition représentent autant de pratiques ascétiques qui fonctionnent comme les rites négatifs mis en évidence par Durkheim (2008). Ces rites négatifs, auxquels doivent se conformer tous les futurs professionnels, distinguent les

13 La musique classique s'éloigne sur ce point d'autres arts, tel le théâtre, où le savoir-faire peut être dans certaines situations directement relié à un savoirêtre (Katz 2006).

14 Sylvia Faure (2000) fait une observation similaire dans le cas de l'apprentissage de la danse.
To understand the necessity of such austere repetition in work, we should not forget that learning an instrument is first and foremost a process of the bodily internalization of practical skill ${ }^{13}$. Technical mastery of the instrument inevitably involves mastery of the body in action ${ }^{14}$. This bodily mastery, leading the musician to instantaneously, almost mechanically produce an appropriate response to an instrumental challenge, is acquired by performing repetitive, compulsory exercises that progressively shape and educate the body to the demands of playing an instrument. The main objective of the study of scales is to physically anchor, through repetition, the suitable fingering for each situation, which in the words of Bourdieu (1977) quoted by Loïc Wacquant (2003: 60), leads to the replacement of the "savage body ... with a "body habituated,' - that is, temporally structured."

The young musicians' absolute commitment to practising their instrument, measured by the amount of personal work to which they subject themselves, is thus embodied in ascetic behaviours. Cutting ties with the profane world, overcoming physical pain and learning through repetition are ascetic practices that function like the negative rites evidenced by Durkheim (2008). These negative rites, which all future professionals must observe, distinguish young musicians as extraordinary individuals. As they successfully conform

13 Classical music differs in this sense from other art forms, such as theatre, in which skill can in some situations relate directly to a way of being (Katz 2006).

14 Sylvia Faure (2000) also observes this in dance education. 
jeunes musiciens qui apparaissent alors comme des individus hors du commun. En parvenant à se conformer à des pratiques ascétiques, qui sont par essence contraignantes et coercitives, et qui, de ce fait, contribuent à l'élimination d'un certain nombre de prétendants, les futurs professionnels confortent leur croyance et celle des autres dans l'authenticité de leur vocation.

\subsubsection{Les modes d'inculcation}

Les conditions d'apparition de cette discipline du corps et de l'esprit nécessitent une analyse. Là encore, les facteurs explicatifs que nous allons dévoiler s'éloignent de la vision indigène. En effet, le sens commun musical attribue les comportements ascétiques à un rapport passionnel à la musique et à l'instrument. Le renoncement au monde extérieur et la recherche de la perfection par l'acharnement au travail proviendraient d'un «coup de foudre », ressenti dès les premiers temps de la pratique. Loin d'apparaître comme une obligation, le travail de l'instrument serait alors la réalisation d'une passion, comme l'affirme Jacques, trompettiste déjà cité en amont.

«Vraiment j'aimais ça. Avant ça, je voulais faire médecine. Mais ma maman serait encore là, elle te dirait que j'avais pas fini de manger mon yaourt, que je descendais en bas et je travaillais ma trompette. Je ne travaillais pas, je jouais. Je jouais, je travaillais en plus de ce que mon prof me donnait à faire. Je jouais des Telemann, des Haendel, des Tartini, etc. Je me faisais plaisir. Je jouais beaucoup, beaucoup. [...] Et puis je te dis quand j'ai mis ça là-dessus [II montre sa trompette puis ses lèvres], et puis que j'ai joué, j'ai dit : "Bon, ça sera ça. Ça sera pas médecine." » to ascetic practices which are in essence binding and coercive - and as such filter out a number of aspirants - future professionals reinforce their belief and the belief of others in the authenticity of their vocation.

\subsubsection{Modes of inculcation}

The conditions in which this discipline of the body and mind appears require analysis. Again, the factors identified here conflict with indigenous views. Indeed, common wisdom in music attributes ascetic behaviours to a passionate relationship to music and to the instrument. The argument is that musicians give up on the outside world and seek perfection through hard work because they "fall in love" with music at a very early stage in their practice. Instead of an obligation, their work is presented as the fulfilment of a passion, as Jacques, the aforementioned trumpet player, explains:

"I really liked it very much. Before that, I wanted to study medicine. But if my mother was still here, she'd tell you that right after finishing my yoghurt I would go downstairs and practise my trumpet. I wasn't working; I was playing. I was playing, working on things beyond my teacher's homework. I'd play Telemann, Handel, Tartini, etc. I had fun. I used to play quite a lot, really. ... And then I'm telling you, once I put this here [he points to his trumpet, and then to his lips], and played, I went: 'Well, that's what it's going to be. Not medicine."' 
Ce discours enchanté, qui associe le travail au plaisir ${ }^{15}$ comme le montre la confusion des verbes «travailler » et « jouer »-, présente l'adoption des pratiques ascétiques comme la conséquence d'une conversion personnelle motivée par un désir individuel. L'investissement total du musicien dans la pratique serait dicté par la rencontre quasi magique entre un instrument et un individu « fait pour ça », qui développerait, dès lors, un rapport passionnel à l'activité musicale et déploierait toute son énergie pour progresser ${ }^{16}$. S'il ne s'agit pas ici de remettre en cause la conviction des agents dans ce modèle, il convient toutefois de démontrer que les pratiques ascétiques ne sauraient s'imposer d'ellesmêmes. Le culte de l'effort et le sens du travail font l'objet d'une inculcation à laquelle participent conjointement la famille et les enseignants.

L'action pédagogique des professeurs contribue ainsi à la progressive soumission des jeunes musiciens à une discipline de travail. L'enseignant émet, dès les débuts de l'apprentissage, des injonctions quant au volume et à la nature du travail personnel. Chaque semaine, des devoirs, sous la forme de morceaux ou de gammes, sont donnés. L'enseignant insiste fortement sur la nécessité d'effectuer ce travail personnel, sans lequel l'apprenti musicien ne saurait

15 On retrouve ici dans le domaine musical, le même mécanisme qu'observe Jacques Defrance (1987 : 182) à propos du sport, c'est-à-dire « un processus de dénégation qui ne permet à cet univers de pratique de fonctionner qu'à la condition de se penser comme un monde social inversé où la peine est transfigurée en plaisir et le travail en jeu ».

16 Julien Bertrand (2009) fait un constat similaire concernant les apprentis footballeurs.
This passionate discourse, equating work with pleasure ${ }^{15}$ as is shown by the indifferent use of "playing" and "working"presents the adoption of ascetic practices as the consequence of a personal conversion motivated by individual desire. According to this view, the musician's total commitment to practice is dictated by the almost magical encounter between an instrument and an individual made to play it, who subsequently develops a passionate relationship to music activity and puts all their energy into improving ${ }^{16}$. While I do not question the agents' belief in this model, it is important to demonstrate that ascetic practices are not as self-evident as they are thought to be. The cult of effort and the sense of work are jointly inculcated by family members and teachers.

The pedagogic work of the professors thus contributes to progressively instilling a work discipline in young musicians. From the early stages of their education, they are issued with recommendations by teachers pertaining to the volume and nature of individual practice. They are given homework each week, in the form of pieces or scales to practise. Teachers strongly emphasize the necessity of doing this individual practice, without which young musicians cannot improve and advance in the curriculum. They check at the beginning

15 Here we find the mechanism as analysed by Jacques Defrance (1987: 182) regarding sport in the music world, namely a "process of denial that allows this universe of practice to function only under the condition of conceiving itself as an inverted social world where pain is transfigured into pleasure and work into play."

16 Julien Bertrand (2009) observes a similar process in young football players. 
progresser et évoluer dans le cursus d'études. II vérifie d'ailleurs en début de cours si les devoirs donnés ont bien été réalisés. Chaque séance s'ouvre par la répétition de la gamme, puis par l'étude du morceau déchiffré à la maison. Les remarques cinglantes ne manquent pas de s'abattre sur l'enfant qui n'a pas satisfait aux exigences de l'enseignant. Aux injonctions concernant le travail à domicile, s'ajoute la façon de mener les cours. Le professeur y privilégie l'apprentissage par la répétition. De nombreuses minutes peuvent ainsi être consacrées à l'étude d'un passage précis, repris plusieurs fois d'affilée jusqu'à ce que l'interprétation de l'élève donne satisfaction. Cette méthode pédagogique qui privilégie la répétitivité et la minutie du geste ancre alors l'idée que la technique instrumentale ne peut se parfaire que par l'acharnement au travail.

Transparaît ainsi le caractère aride de l'enseignement musical. Les cours ne sont pas associés à des moments de plaisir ou d'épanouissement pour l'élève, mais constituent des phases de travail intensif et répétitif où l'apprenti musicien fait l'apprentissage de la souffrance, aussi bien sous la forme d'une fatigue physique que d'une insatisfaction morale devant les difficultés rencontrées avec l'instrument. Chaque séance est l'occasion d'une inculcation de comportements ascétiques, que prolongent les injonctions enseignantes concernant le travail à domicile. La relation avec le professeur contribue également à renforcer la soumission à la discipline de travail. La recherche de l'approbation et des félicitations d'un pédagogue, qu'ils considèrent comme un " maître » (Wagner 2004), pousse également les apprentis musiciens à se lancer dans un travail personnel acharné of each class whether homework has been done. Each class begins with the repetition of a scale and the study of a piece sight-read at home. Children who do not meet the teachers' demands face scathing reprimands. In addition to the injunctions to do homework, discipline is also drilled in class. Teachers favour learning through repetition. A short passage may be examined painstakingly for several minutes and replayed multiple times until the student's performance proves satisfactory. Such teaching methods, laying emphasis on repetition and meticulous action, drive home the idea that instrumental technique can only be perfected through hard work.

This gives a sense of the dullness of music education. Students do not associate classes with enjoyment or selffulfilment; they are phases of intensive, repetitive work where they learn to suffer-both in the form of the physical toll on their bodies and of moral dissatisfaction in the face of their struggles with the instrument. Each class is an opportunity to inculcate ascetic behaviours, reinforced by the teachers' demands regarding homework. Student-teacher relationships also contribute to reinforcing adherence to this work discipline. The search for approval and praise from a teacher they consider to be a "master" (Wagner 2004) is part of what drives young musicians to commit to such hard work. 
L'inculcation d'un rapport ascétique à la pratique instrumentale ne s'opère néanmoins pas uniquement au sein des conservatoires. L'environnement familial participe également à ce processus en incitant, plus ou moins explicitement, le jeune musicien à se plier aux exigences de leur professeur (Burland \& Davidson 2004). Dans les familles musiciennes, l'inculcation des pratiques ascétiques s'opère par la transmission d'un ethos musical, c'est-à-dire un « sens moral » de la pratique instrumentale ${ }^{17}$. Les parents, étant persuadés de la nécessité et du bien-fondé d'un investissement total dans l'activité instrumentale, dont eux-mêmes ont fait l'expérience, ne conçoivent l'apprentissage instrumental de leur enfant que sous l'angle d'un rapport ascétique. Ce faisant, ils font du travail personnel intensif une obligation morale à laquelle doit se plier leur progéniture. Cette transmission peut prendre des formes relativement douces fondées sur l'imitation, mais n'exclut pas des formes beaucoup plus coercitives, comme le montre l'exemple de Jeanne, violoncelliste, citée en amont.

« II y avait des jours où ma mère m'enfermait parce qu'elle trouvait que je ne travaillais pas assez. [...] Et ma mère poussait des hurlantes sans arrêt en me disant : "Va travailler! Va travailler !" »

Les familles musiciennes n'ont toutefois pas le monopole de l'inculcation des pratiques ascétiques. En effet, ce rapport à l'ascèse ne constitue pas une spécificité propre à l'ethos

17 Pour une description, dans un autre champ de production intellectuelle d'un ethos professionnel qui partage certains traits communs avec l'ethos des musiciens (retrait du monde, dimension passionnelle de la pratique, comportements ascétiques), voir Zarca (2009).
This ascetic relationship to playing an instrument does not solely operate in conservatories. Families are also part of the process, as they encourage in more or less explicit terms these young musicians to comply with teachers' demands (Burland \& Davidson 2004). In musicians' families, the inculcation of ascetic practices involves the transmission of a musical ethos - a "moral sense" of playing an instrument ${ }^{17}$. Parents, persuaded of the necessity and merit of total commitment to the instrumental activity, having experienced it themselves, cannot conceive of their child's instrumental education other than from the angle of asceticism. Hence, they consider intensive individual practice to be a moral obligation for their offspring. This transmission can take on relatively soft forms, based on imitation, but it can also be much more coercive, as in the case of Jeanne the cellist:

"There were days when my mother would lock me inside because she thought I wasn't practising enough ... She'd constantly yell at me: 'Go and practise!', 'Go and practise!'”

Musicians'families, it should be noted, do not have a monopoly on the inculcation of ascetic practices. This relationship to asceticism is not specific to the music ethos. One finds it

17 For a description of a professional ethos that shares traits with the musicians ethos (withdrawal from the world, the passionate dimension of practice, ascetic behaviours) in another field of intellectual production, see Zarca (2009) 
musical. On le retrouve dans une morale de travail petitebourgeoise (Bourdieu 1979) qui n'est pas circonscrite à cette catégorie sociale mais touche également des individus tendus vers l'ascension ${ }^{18}$. Au sein de familles dépourvues de connaissance musicale, peut donc se transmettre un « sens moral » du travail qui s'accorde avec les exigences de l'apprentissage instrumental. Percevant la rigueur de l'enseignement musical et les impératifs de l'investissement total dans la pratique comme " une éducation morale fondée sur la vertu de l'engagement dans le travail » (Laillier 2011 : 79), les parents incitent à l'adoption de pratiques ascétiques. Sans forcément rêver à un devenir professionnel pour leur enfant, mais en anticipant plutôt les «bienfaits » d'une socialisation à l'effort, les parents mus par la morale petitebourgeoise offrent un cadre propice à l'incorporation des pratiques ascétiques.

L'engagement total dans la pratique instrumentale doit donc être interprété comme l'activation de dispositions héritées favorisant la représentation de l'activité professionnelle sur le modèle du « don de soi ». Le cadre familial produit en outre certaines des conditions de l'activation de ces dispositions. En effet, les investissements matériels et symboliques consentis au cours de l'éducation musicale incitent le jeune instrumentiste à offrir à sa famille une contrepartie symbolique dont la forme minimale consiste en un engagement total dans

18 Olivier Schwartz (1990) souligne combien certains ouvriers envisageant pour leurs enfants une sortie des classes populaires insistent fortement sur l'investissement dans le travail scolaire et le retrait des lieux de sociabilité ouvrière. in the petit-bourgeois work ethic (Bourdieu 2013) that also characterizes individuals with aspirations of upward mobility ${ }^{18}$. Thus, families with no musical background may pass on a "moral sense" of work that ties in with the demands of music education. Perceiving the rigour of music education and the imperatives of total commitment to playing an instrument as a "moral education founded on the virtue of a commitment to work" (Laillier 2011: 79), parents encourage the adoption of ascetic practices. Without necessarily dreaming of a professional future for their children, but anticipating the benefits of a socialization that emphasizes effort, such parents, inspired by the petit-bourgeois ethic, offer a framework that is conducive to the bodily internalization of ascetic practices.

Total commitment to playing an instrument should therefore be interpreted as the activation of inherited dispositions that support representations of professional activity in terms of self-sacrifice. Families also provide some of the conditions for activating these dispositions. Indeed, the material and symbolic investments made during music education encourage young instrumentalists to offer their families symbolic compensation-the minimal form of which being total commitment to learning the instrument. The purchase of the instrument and sheet music, enrolment in a conservatory

18 Olivier Schwartz (1990) stressed that some blue-collar workers who aspire to move their children out of the working class strongly emphasize investment in schoolwork and withdrawal from places of working-class socialization. 
la pratique. Les achats d'un instrument et de partitions, les coûts de l'inscription au conservatoire et dans les stages, l'assistance aux auditions et aux concerts, les manifestations de soutien représentent autant de dons familiaux qui conditionnent en retour un contre-don de la part du jeune musicien passant nécessairement par la démonstration de son investissement dans la pratique (Mauss 2004). Parce que l'économie domestique fonctionne selon une logique spécifique fondée sur l'échange de biens symboliques (Bourdieu 1994), l'apprenti musicien est contraint par une forme d'obligation morale de répondre aux investissements familiaux par l'adoption d'une discipline personnelle de travail.

Tout comme la croyance dans le don, les conduites ascétiques sont donc le fruit d'un processus collectif de socialisation qui met aux prises conjointement la famille et les institutions de formation musicale. Talent et ascèse forment alors un couple indissociable consacrant la vocation des instrumentistes : sans croyance dans le talent, point d'investissement ascétique et sans investissement ascétique, point de virtuosité. Il est ainsi inopportun d'opposer «illusion du don et réalisme du travail car ce réalisme méconnaît la force de l'illusion ${ }^{19}$ » et confère ainsi au sentiment vocationnel une connotation naturalisante.

\subsection{De la vocation musicale à l'orientation vers l'enseignement}

À ce stade de l'analyse, ont été abordés les principes de construction juvénile du sentiment vocationnel des futurs

19 Je remercie Gérard Mauger pour cette remarque inscrite dans le rapport de soutenance de la thèse. and on internships, and help and demonstrations of support at auditions and concerts are all family gifts that work as a condition of a counter-gift from young musicians, which necessarily involves the demonstration of their investment in playing an instrument (Mauss 2011). As the domestic economy operates according to a specific logic based on exchanging symbolic goods (Bourdieu 1998), young musicians are bound by a form of moral obligation to respond to family investments by adopting a personal work discipline.

Like belief in the gift, ascetic behaviours are the outcome of a collective socialization process jointly involving families and music education institutions. Talent and asceticism come to form an inseparable pairing that is a core component of the instrumentalist's vocation: without belief in talent, there is no ascetic investment and no virtuosity. We should therefore refrain from setting the "illusion of the gift" against "the realism of work, as this realism ignores the force of illusion ${ }^{19}$," and confers a naturalizing dimension on the sense of vocation.

\subsection{From musical vocation to teaching}

At this stage in the analysis, I have examined the principles of the early construction of a sense of vocation in future

19 Thanks are due to Gérard Mauger for this remark made in the post-defence report of my thesis. 
musiciens. Poursuivre l'analyse consiste à étudier comment cette vocation se concrétise en insertion professionnelle, et plus spécifiquement dans le cas de la population étudiée, en engagement dans une carrière enseignante. $\mathrm{Ce}$ questionnement amène à relever la diversité des modes d'orientation vers la pédagogie. Les étapes menant à se détourner des métiers les plus valorisés de l'interprétation (permanents d'orchestre et solistes internationaux) et à la progressive conversion à l'activité pédagogique ne surviennent ainsi pas au même moment des trajectoires des

enquêtés.

Pour une partie de la population étudiée (un cinquième), le deuil des « grands métiers » (Zunigo 2010) s'opère pendant la période de formation et se traduit par un renoncement à se présenter au concours d'entrée des CNSM. Persuadés, par leurs enseignants et l'organisation même du système d'enseignement, de leur incapacité à atteindre l'excellence instrumentale, ils incorporent très tôt un " sens des limites musicales ${ }^{20}$ faisant de l'orientation vers l'enseignement le seul devenir possible. Cette dimension traduit l'efficacité du système de formation musicale. Capable de produire des instrumentistes occupant les positions les plus élevées, celui-ci est également en mesure de fabriquer des musiciens destinés aux positions modestes et qui se satisfont de ces positions ${ }^{21}$. Parce qu'il est fondé sur un principe continuel de

20 Sophie Orange (2013) montre un mécanisme similaire pour les étudiants de BTS.

21 Le système d'enseignement musical se rapproche alors, mutatis mutandis, du système scolaire capable également de produire des professionnels musicians. Pursuing this analysis further requires investigation into how this vocation materializes in the labour market andmore specifically when it comes to the population under study -in the form of teaching careers. This brings me to note the diversity of the paths which lead to a career in teaching. The stages at which the young musicians turn away from the most prestigious performing positions (as full-time orchestra members or international soloists) and progressively turn to teaching do not happen at the same points in the interviewees' trajectories.

Part of the population (one in five musicians) renounces the "great occupations" of music (Zunigo 2010) during the course of their training, and as a result does not take the entrance exam to access the top national music conservatories (hereafter CNSM). Having been persuaded by their teachers and the very organization of the education system that they will be unable to reach instrumental excellence, these musicians internalize a "sense of musical limitations ${ }^{20 "}$ at a very early point, making teaching the only possible outcome of their training. This shows how effective the music education system is. Not only does it produce instrumentalists who go on to hold the highest positions, but it also turns out musicians that are destined to hold lower positions which they can be content with $^{21}$. Being based on continual differentiation according to

20 Sophie Orange (2013) evidences a similar mechanism in students of French technical certificate courses (BTS).

21 In this sense, the music education system resembles the general education system, which is also capable of producing professionals destined for lower positions who are fully aware of this outcome (Grignon 1971) 
différenciation, sur la base des qualités musicales innées ou du « talent » des instrumentistes, ce système de formation est en mesure d'imposer un mode de classement aux musiciens, mode de classement qui leur apparaît d'autant plus légitime qu'il est construit sur un modèle naturaliste dans lequel se reconnaissent tous les instrumentistes. L'idéologie du don étant au fondement de leur élection, ces jeunes instrumentistes ne peuvent contester et doivent adhérer au mode de classement naturaliste, qui les destine pourtant au bas de la hiérarchie musicale avant même la fin de leur formation. Cette conscience précoce les conduit à une forme d'auto-exclusion, à raisonner leurs ambitions et à développer une perception positive de l'emploi d'enseignant.

Le concours d'entrée du CNSM constitue un second moment charnière de la différenciation des trajectoires des instrumentistes étudiés. II opère une sélection entre ceux qui l'ont réussi pour qui la professionnalisation est désormais acquise ${ }^{22}$ et les aspirations d'excellence demeurent possibles, et ceux qui l'ont raté pour lesquels l'accès aux métiers

destinés aux positions dominées et ayant pleinement intégré cet état de fait (Grignon 1971).

22 Les travaux d'Eddy Schepens (1995) sur les anciens étudiants des CNSM de Paris et de Lyon de 1979 à 1990 considèrent que l'ensemble de l'échantillon est professionnalisé. Des données plus récentes, établies par le pôle « Études et statistiques » du CNSM de Paris, sur l'insertion trois ans après leur diplôme des instrumentistes lauréats des années 2003, 2004 et 2005 ( $n=265$ ) estiment que seulement 1,9\% ne sont pas employés dans le secteur musical. (Sources : Enquêtes internes du CNSMD de Paris sur l'activité professionnelle des diplômés à $n+3$, données récoltées en 2007 , 2008 et 2009. Je remercie Mme Danièle Robin pour m'avoir transmis ces données.) the innate musical skills or the "talent" of instrumentalists, this training system is able to impose a particular form of ranking on musicians that appears all the more legitimate to them as it is constructed on a naturalistic model that all instrumentalists subscribe to. As the ideology of the gift is crucial to their being chosen, these young instrumentalists are bound to support a naturalistic ranking system even as it steers them towards the lower levels of the music hierarchy before they have completed their training. This early awareness leads to a form of self-exclusion; they curb their ambitions and develop a positive perception of teaching work.

The CNSM entrance exam is a second milestone in the differentiation of instrumentalists' trajectories. It introduces selection between those who pass, for whom professionalization is now a given ${ }^{22}$, and who may continue to aspire to excellence, and those who fail, whose access to musical occupations is uncertain and who only have a clear future in teaching. In this sense, this exam works as an act of institution that "creates differences of all or nothing" (Bourdieu 1982: 120). For the unsuccessful candidates

22 In Eddy Schepens's research (1995) on CNSM alumni in Paris and Lyon from 1979 to 1990 , the entire sample is professionalized. More recent data from the statistics department of the Paris CNSM on the placement of instrumentalists who graduated in 2003, 2004, and $2005(n=265)$ suggest that three years after graduation, only $1,9 \%$ are not employed in the music sector. (Sources: Enquêtes internes du CNSMD de Paris sur l'activite professionnelle des diplômés à $n+3$, data collected in 2007, 2008, and 2009. I wish to thank Ms. Danièle Robin for sending me these data.) 
musicaux est incertain et seulement possible dans le secteur de l'enseignement. Ce concours opère, en ce sens, comme un acte d'institution " créant des différences du tout ou rien » (Bourdieu 1982 : 60). Pour les « recalés» (un tiers de la population), l'échec est brutal. À la désillusion de leur rêve de grandeur musicale, s'ajoute le fait de ne pas avoir su répondre positivement aux attentes familiales et professorales. En effet, le projet d'intégrer un CNSM nécessite un soutien professoral, sous la forme d'une recommandation permettant d'intégrer les classes préparatoires au concours, ainsi qu'une adhésion familiale, autant financière pour supporter le coût des phases de préparation au concours ${ }^{23}$ que morale pour soutenir un objectif par essence incertain ${ }^{24}$. Conséquence d'un échec, leur réorientation vers les métiers de l'enseignement est perçue comme une relégation dans l'univers musical.

Le troisième modèle de trajectoire menant à l'enseignement concerne la moitié de la population étudiée passée par un CNSM. Pour ces instrumentistes détenteurs de la formation la plus aboutie en musique classique, c'est la confrontation avec la structure du marché du travail musical qui les pousse à s'engager dans une carrière enseignante. Car le passage

23 La préparation au concours du CNSM nécessite de prendre des cours de perfectionnement auprès de professeurs renommés, autant pour améliorer la technique instrumentale que pour se faire connaître auprès des membres du jury du concours d'entrée. Ces professeurs officiant souvent dans des institutions parisiennes, une telle disposition implique, pour les instrumentistes provinciaux, un investissement économique pour s'installer à Paris ou financer les trajets. Pour plus de détails, sur les concours d'entrée des CNSM, voir Pégourdie (2013).

24 Joël Laillier (2011) fait un constat similaire concernant l'investissement des parents des jeunes élèves danseurs, les « petits rats », de l'Opéra. (a third of the population), failure is brutal. They lose their illusions regarding their dreams of musical grandeur, and have to deal with their inability to meet the expectations of their families and teachers. Indeed, the project of enrolling in a CNSM requires support from teachers, in the form of a recommendation allowing access to a preparatory course for the exam, and support from family - both financial, to pay for the costs of preparation ${ }^{23}$ and moral, as the student's objective is by nature uncertain ${ }^{24}$. Being the consequence of a failure, their change of trajectory towards teaching is perceived as relegation in the music world.

The third model of trajectory leading to teaching concerns half of the population under study - those who have been to a CNSM. For these instrumentalists who have the highest possible training in classical music, the challenge posed by the structure of the labour market is the reason for pursuing a teaching career, since studying at a CNSM is an almost mandatory condition (Lehmann 2005) but does not guarantee

23 Preparing for the CNSM entrance exam requires taking advanced courses with renowned teachers, both to improve instrumental technique and to make oneself known to members of the jury. As these teachers often work in Parisian institutions, this requires a financial investment for provincial instrumentalists, either to move to Paris or to fund trips. For more on the CNSM entrance exam, see Pégourdie (2013).

24 Joël Laillier (2011) makes a similar observation regarding parents' investment in young student dancers, the "little rats" of the Opera. 
par le CNSM est une condition quasi nécessaire (Lehmann 2005) mais pas suffisante pour prétendre aux postes les plus valorisés. Le faible nombre de solistes internationaux et la concurrence féroce lors des concours de permanents d'orchestre (Ravet 2007) pousse vers l'enseignement un nombre conséquent de diplômés du CNSM. Les logiques de cette orientation renvoient aux inégalités sociales structurant le marché du travail musical. Pour les saisir, il faut rappeler que les familles instrumentales se distinguent entre un pôle féminisé au recrutement social élevé, les cordes, et un pôle masculin au recrutement social moins sélectif, les vents (Coulangeon 2004 ; Lehmann 2005). Cette différenciation sociale se traduit en inégalités sur le marché du travail musical. Les interprètes d'instruments à vent étant soumis à une plus forte restriction de leurs possibles professionnels, notamment dans le secteur de l'interprétation, que les interprètes plus « nobles » socialement des cordes (Pégourdie 2015a), ils doivent plus fréquemment se « contenter » d'un emploi d'enseignant. Cette inégalité instrumentale, et par là sociale, sur le marché du travail se double d'une inégalité sexuelle. Au sein du pôle féminisé des cordes, on observe un mécanisme de ségrégation sexuelle verticale rendant plus difficile l'accès aux positions dominantes pour les femmes (Coulangeon \& Ravet 2003). Sont ainsi tendanciellement orientés vers la pédagogie, les instrumentistes à vent et les interprètes féminines des cordes. Reste alors à se faire à ces inégalités instrumentales, qui masquent des inégalités sociales, et à concilier pédagogie et formation d'excellence ${ }^{25}$.

25 Pour une analyse détaillée de la progressive intériorisation de l'enseignement comme carrière honorable à partir de l'étude de deux trajectoires de diplômés du CNSM, voir Pégourdie (2015b). access to the most prized positions. The low number of international soloists and the fierce competition in exams for fulltime positions in orchestras (Ravet 2007) steer many a CNSM graduate towards teaching. The logics of such trajectories reflect the social inequalities that structure the music labour market. To understand them, we must recall that there is a division between the families of string instruments-with a predominance of women and high social backgrounds-and wind instruments - where men with lower social backgrounds prevail (Coulangeon 2004; Lehmann 2005). This social divide is reflected in inequalities in the labour market. Wind players have a more restricted set of professional opportunities, particularly in the field of performance, than the more socially "noble" string players (Pégourdie 2015a); they more often have to make do with a teaching position. This instrumental and social inequality in the labour market comes with gender inequality. Within the feminized group of string players, we observe a vertical gender segregation mechanism that makes access to dominant positions difficult for women (Coulangeon \& Ravet 2003). Wind players and female string players thus tend to turn to teaching. They must then cope with these instrumental and social inequalities and reconcile teaching with their high-level training ${ }^{25}$.

25 For detailed analysis of the gradual internalization of teaching as an honourable career based on the study of two trajectories of CNSM graduates, see Pégourdie (2015b). 


\section{L'entretien des vocations}

Persuadés de leur don et rompus à une vision ascétique du travail musical pendant leur période de formation, les instrumentistes classiques étudiés doivent faire face lors de leur entrée dans le monde professionnel à la réalité de leur condition enseignante. Ils n'ont pu atteindre les positions dominantes du champ de la musique classique et les rétributions symboliques qui y sont associées. Ayant dû faire le deuil de leurs aspirations à l'excellence, ils sont également confrontés à la possible remise en question des principes mêmes de leur vocation. Pour faire face à cette désillusion et maintenir leur vocation, ils doivent alors requalifier l'enseignement et accorder à cette activité une valeur symbolique. Ils s'engagent ainsi dans diverses stratégies de réassurance basées sur les fonctions sociales présumées de la pédagogie musicale. Leur vocation parvient à se maintenir par le biais d'une interprétation de l'activité pédagogique dont les ressorts divergent selon leur trajectoire antérieure et leur

position actuelle.

\subsection{L'enseignement au service de l'activité artistique}

Le premier mode de requalification de l'enseignement se rencontre parmi la fraction la plus diplômée des pédagogues du conservatoire à rayonnement régional (CRR) enquêté : les professeurs. Au sein de cet établissement situé en position intermédiaire dans la structure pyramidale de l'enseignement musical français (au second des cinq échelons), sont employés des instrumentistes titulaires de titres musicaux prestigieux: un diplôme du CNSM et un certificat d'aptitudes (CA) aux

\section{Maintaining vocations}

Having been persuaded of their gift and used to an ascetic vision of music practice during their training, classical instrumentalists must face the reality of their condition as a teacher as they enter the professional world. They have failed to reach the leading positions in the classical music field and their associated symbolic rewards. Having renounced their aspirations of excellence, they also face a possible challenge to the very foundations of their vocations. To deal with such disillusion and maintain their vocations, they must reassess teaching and grant it symbolic value. This involves turning to a variety of reassurance strategies focusing on the supposed social functions of music education. They maintain their vocation by resorting to interpretations of teaching, the mechanisms of which differ according to past trajectory and current position.

\subsection{Teaching at the service of artistic activity}

The first form of reassessment of teaching is found among the most educated fraction of the teaching staff in the regional conservatory (CRR) under study: the professors. The institution, whose position is intermediate in the pyramid structure of French music education (the second of five levels), employs instrumentalists who hold prestigious music qualification: a CNSM degree and a certificate of aptitude 
fonctions de professeur de musique ${ }^{26}$. Cette population spécifique, du fait du décalage entre aspirations initiales et réalité de leur condition actuelle, adopte un discours original sur l'enseignement. Ces professeurs, passés par les CNSM et ayant donc pour la plupart projeté durant leur formation une carrière dans l'interprétation, instaurent une façon particulière de percevoir et de pratiquer l'enseignement qui tente de rendre conciliable excellence instrumentale et pédagogie dans un conservatoire intermédiaire.

Leurs modes de perception et d'exercice de la pédagogie se concentrent dans l'affirmation du lien étroit, de la complémentarité entre l'enseignement et l'interprétation. La pédagogie aurait alors pour fonction d'enrichir leur activité artistique. Ils s'évertuent à démontrer l'importance de la capacité artistique du pédagogue et la nécessité pour celuici de jouer de son instrument et de se produire en public afin d'être performant dans son travail d'enseignant. La performance instrumentale est conçue comme point central de la pratique pédagogique, replaçant ainsi l'aspect artistique au centre de l'activité professionnelle. Tout cela étant résumé par la formule : «Pour être un bon enseignant, il faut jouer ».

C'est ce que pense Dominique, professeur de cor.

26 II existe deux diplômes d'enseignement musical en France, le CA et le Diplôme d'État (DE) qui accréditent des hiérarchies internes. Les titulaires du CA ont accès au grade de professeur, sont mieux rémunérés, délivrent moins d'heures de cours hebdomadaires et sont censés se consacrer à des élèves plus avancés dans le cursus d'études musicales. Les titulaires du DE ont, quant à eux, accès au grade d'assistant.
(CA) to work as a professor of music ${ }^{26}$. Owing to the gap between their initial aspirations and the reality of their current condition, this population adopts an original discourse on teaching. These professors, who have studied at a CNSM and therefore generally envisaged a career as a performer, have a specific way of teaching and of perceiving teaching which attempts to reconcile instrumental excellence with pedagogy at a mid-level conservatory.

Their modes of perception and practice of pedagogy emphasize the close link and the complementarity between teaching and performance. In this sense, they tend to consider that the function of teaching is to enrich their artistic activity. They are adamant about the importance of the teacher's artistic abilities and the need for he or she to play their instrument and perform in public in order to be a good teacher. Instrumental performance is conceived as a central point of pedagogic practice, thereby replacing the artistic dimension at the heart of the professional activity. All of this is summed up by the phrase: "To be a good teacher, you have to play." Dominique, a horn teacher, explains this in the following terms:

26 There are two musical teaching degrees in France: the CA and the state diploma (DE), which establish internal hierarchies. Those with the CA have access to the grade of professor, are better paid, have a lighter weekly teaching load, and are supposed to focus on more advanced students. Those with the DE have access to the grade of assistant. 
« Le seul problème, c'est qu'un professeur qui ne joue jamais, à terme il ne va pas travailler son instrument dans sa classe pendant trois heures par jour pour rien. C'est humain. [...] Quand vous avez des "grands élèves" qui arrivent, il faut jouer une partition. II faut montrer. C'est pas comme un entraîneur de foot ou de piscine qui chronomètre, qui dit qu'il faudrait mieux faire ça mais qui montre pas. Nous, on joue à la place de l'élève, on lui montre. Un professeur qui ne montre pas, il n'a pas de classe. Les élèves quand ils ont passé $5 / 6$ ans avec le prof, qu'ils arrivent à 14/15 ans, ils sont critiques. Si le prof joue pas ou montre des défauts, ça ne marche pas. Mais si le professeur montre vraiment une différence entre ce que fait un "grand élève" et ce qu'il fait lui, c'est bien. Mais le prof qui laisse l'instrument dans la boîte et qui vient sans instrument au conservatoire, ça ne va pas du tout. »

Cette centralité de la dimension artistique de l'enseignant dans le procédé de transmission des savoirs musicaux, qui place la capacité artistique au centre du processus pédagogique, amène les professeurs à totalement requalifier leur pratique enseignante et à la considérer comme une activité complémentaire de la performance instrumentale. Si un bon enseignement requiert une pratique assidue du pédagogue, la pédagogie lui permet également d'améliorer son interprétation. L'enseignement se détourne d'une relation unilatérale dans laquelle l'élève reçoit le savoir de l'enseignant, pour devenir une construction bilatérale où l'apprentissage de l'étudiant profite aussi à l'enseignant ${ }^{27}$. Ce dernier, en revenant sur les difficultés de la pratique musicale

27 Nicolas Jounin (2014) adopte une perception similaire de la relation pédagogique en sociologie.
"The only problem is that a teacher who never plays, ultimately, they're not going to work on their instrument in class three hours a day for nothing. It's human. ... When you have 'top students' coming in, you have to play a score. You have to show them. It's not like a football or swimming trainer with their stopwatch, who says 'you should do this better,' but without demonstrating. We play for the student; we show them. A teacher who doesn't demonstrate anything has no class. Make no mistake, once students have spent five/six years with a teacher, they get to 14 or 15 , and they can be critical. If the teacher doesn't play or their playing is flawed, things aren't going to work out. But if a teacher can really show the difference between what a 'top student' does and what they do themselves, then that's fine. A teacher who leaves their instrument in the box and shows up without their instrument at the conservatory isn't going to cut it."

The central role granted to the teacher's artistic skills in the process of transmission of musical knowledge leads teachers to reassess their teaching practice entirely and consider it as a complement to playing an instrument. Good teaching requires assiduous practice from the teacher, but teaching also allows them to improve their practice. Instead of being a one-sided relationship whereby the student simply receives the teacher's knowledge, teaching becomes a bilateral construction in which the student's learning process also benefits the teacher ${ }^{27}$. As teachers face the challenges of musical practice and offer solutions to overcome them, they keep perfecting their own instrumental technique. Elizabeth, a

27 Nicolas Jounin (2014) has a similar take on the pedagogic relationship in sociology. 
et en proposant des solutions pour pallier à ces problèmes, ne cesse de perfectionner sa propre technique instrumentale. Elizabeth, professeure de flûte traversière, soulève ainsi la complémentarité entre pédagogie et interprétation.

" Moi, je considère que ce sont deux métiers complémentaires. Pour pouvoir enseigner à des jeunes ce qu'il faut faire avec un instrument, la manière de jouer tel ou tel morceau, la façon de faire passer des émotions, il faut être capable de pouvoir le faire soi-même. C'est pour ça qu'il faut continuellement jouer, et en plus face à un public, pour toujours comprendre ce qu'on leur apprend. Et l'enseignement, c'est pareil. Ça permet de voir chez des élèves certaines erreurs et de les corriger, puis de se demander si nous, également, on ne fait pas ces erreurs. Comme ç, des fois, on arrive à se rendre compte qu'on n'est pas juste à un endroit. Et puis, on se corrige et on est meilleur quand on joue dans l'orchestre. »

En requalifiant l'activité d'enseignement en espace de recherche et de réflexion sur la pratique artistique du musicien, les professeurs s'assimilent au modèle de l'artiste, constamment préoccupé par la quête de la perfection esthétique ${ }^{28}$. Cependant une telle redéfinition de l'enseignement ne peut se concevoir qu'avec des élèves ayant atteint une certaine maîtrise instrumentale. Elle n'est pertinente qu'en présence d'étudiants qui sont détenteurs d'une relative maturité musicale et pas pour des débutants. La variable concrète mobilisée par les professeurs pour qualifier

28 Cette question de la recomposition de la référence au mythe de «l'artiste pur » lors de l'entrée dans la carrière enseignante a également été abordée par Pierre-Emmanuel Sorignet (2004) dans le cas des danseurs contemporains. concert flute teacher, points to the complementarity between teaching and performance:

"I consider them to be two complementary jobs. To be able to teach kids what you need to do with an instrument, the way to play a given piece, the way you convey emotions, you need to be able to do it yourself. That's why you need to keep playing, and to play in front of an audience, too, so that you always understand what to teach. Teaching is the same. It allows you to spot some mistakes in students and correct them, and then to ask yourself whether you're not making the same mistakes as well. At times, you come to realize that you're not playing a particular passage right. And then you correct it and you get better when you play in an orchestra."

By redefining teaching as a space for research and reflection on the musician's artistic practice, teachers internalize the model of the artist who is ceaselessly striving towards aesthetic perfection ${ }^{28}$. However, such a redefinition of teaching is only conceivable with students who have reached a sufficient level of instrumental maturity-not with beginners. In effect, the variable used by teachers to assess their practice is the number of students who have secured professional status or enrolled in a CNSM. Teachers rely on the professional careers subsequently followed by students to value the

28 The issue of the refashioned reference to the myth of the pure artist upon entry into a teaching career has also been addressed by Pierre-Emmanuel Sorignet (2004) in the case of contemporary dancers. 
leur pratique devient alors leur nombre d'élèves à avoir atteint le statut professionnel ou intégré les CNSM. C'est par le devenir professionnel de ses étudiants que l'enseignant valorise la qualité de sa prestation et s'institue comme un musicien de talent. Tout se passe comme si les capacités musicales de l'élève étaient le reflet des propres dispositions du professeur. Les élèves se retrouvent alors à remplir une fonction désincarnée de biens symboliques et participent indirectement à la requalification de leurs enseignants qui, grâce à eux, font la preuve de leurs qualités de pédagogues, autant que de leur talent artistique. Ainsi l'enseignement prodigué aux jeunes instrumentistes prometteurs devient un enjeu de luttes pour les professeurs de musique. Enseigner à des " grands élèves » est conçu comme une nécessité. C'est

ce que souligne Yves, professeur de saxophone.

«Moi, j'ai une formation au CNSM de Paris, un certificat d'aptitude, donc un diplôme d'enseignement reconnu au niveau national, sauf qu'on va me demander d'enseigner et d'oublier un peu les diplômes que j'ai reçus. Et c'est là qu'il y a un souci et une dévalorisation du métier parce qu'on vous impose un cursus et une nouvelle formation qui ne correspondent pas à mon cadre d'emploi. Pour moi, ça veut dire qu'on ne s'intéressera plus aux mêmes personnes. Ça ne veut pas dire que j'étais censé m'occuper que de gens qui sont pré-professionnels, parce que ça représente un pourcentage infime dans un conservatoire. Mais j'avais l'espoir d'avoir quelques-uns de ces élèves. Et c'est ce qui se passe aujourd'hui. J'ai des élèves qui présentent Paris [le CNSM], y'en a un qui est entré dans une école internationale en jazz. " quality of their work and consider themselves to be talented musicians. Everything happens as if the students' musical skills where the reflection of the teachers' own dispositions. Students thus come to fulfil a disembodied function as symbolic goods, and indirectly contribute to the redefinition of their teachers as pedagogues and artists. Teaching promising young instrumentalists becomes an object of struggle among music teachers. The necessity of grooming "top students" is illustrated here by Yves, a saxophone teacher:
"The thing is, I was trained at the Paris CNSM, I have a Certificate of Aptitude, which is a nationally recognized teaching degree; except I'm asked to teach and to sort of forget about these degrees I received. That's where the trouble lies and that's where the job loses value-they're forcing a curriculum and a new training on you that no longer matches my job description. To me, that means we're no longer going to focus on the same people. It doesn't mean I was only supposed to work with pre-professionals, because they make up a very small fraction of students in a conservatory. But I had hopes of having some of those students. And that's what's happening today. I have students who are applying for Paris [CNSM]; one of them got into an international jazz school." 
Cette redéfinition de l'enseignement en activité profondément liée à l'interprétation et complémentaire de la performance instrumentale s'inscrit d'ailleurs dans la nature même du travail de plusieurs des professeurs rencontrés dans notre recherche. Le CRR de province sur lequel porte l'enquête a la particularité, contrairement à d'autres structures, de favoriser le cumul des activités d'enseignement et d'interprétation. Plusieurs professeurs cumulent ainsi statutairement une place dans un orchestre symphonique non permanent et un poste au CRR. La complémentarité de l'enseignement et de l'interprétation trouve dans ce cas une expression tangible dans leur statut de «cumulant»: ils sont professeurs au conservatoire en même temps qu'ils sont instrumentistes dans un orchestre et leurs discours reliant enseignement et interprétation sont parfaitement ajustés à leurs pratiques. Le modèle de requalification de la pédagogie correspondant à la réalité concrète de leur activité professionnelle, ils appréhendent donc de manière positive l'enseignement, en l'intégrant à une pratique artistique globale. L'adéquation entre le processus de revalorisation de l'enseignement et la nature des activités est cependant moins évidente pour les professeurs qui n'interviennent pas dans un orchestre. Ceuxci trouvent alors dans des prestations ponctuelles en soliste et/ou dans des ensembles de musique de chambre, une voie de salut leur permettant de s'épanouir artistiquement, de combler leur ambition d'interprète avortée et de se prémunir, pas toujours avec succès, contre le désenchantement pédagogique.
This redefinition of teaching as an activity that is intrinsically linked to and complements instrumental performance actually ties with the very nature of the work done by several of the teachers I met for this research. Unlike other structures, the provincial CRR under study encourages the pursuit of both teaching and performance. Thus, a number of teachers are both part-time members of a symphonic orchestra and holders of a position at the CRR. In such cases, the complementarity between teaching and performance is made tangible by the coexistence of their two statuses: their discourse connecting teaching and performance is perfectly adjusted to their practice. As this model of redefinition of teaching fits the concrete reality of their professional activity, they have a positive approach to teaching, which they include in their global artistic practice. The fit between the process of the reassessment of teaching and the nature of their activities is, however, not so evident for teachers who do not play in an orchestra. To avoid becoming disenchanted with teaching, they have to find ways to nurture their unfulfilled ambitions in occasional performances as soloists and/or in chamber music ensembles. 


\subsection{Encadrer la jeunesse}

Le second modèle de requalification de l'activité enseignante se rencontre également au sein du CRR enquêté. II est porté par les pédagogues possédant des titres musicaux moins élevés : les assistants. Ces derniers sont détenteurs du Diplôme d'État (DE) et n'ont pas effectué leur formation dans les CNSM. La plupart a pourtant envisagé, au seuil de la majorité, d'intégrer ces conservatoires d'excellence. Malheureusement des échecs répétés au concours d'entrée leur ont fermé les portes de la formation d'élite et, par voie de conséquence, des positions dominantes du champ de la musique classique. Face à ces échecs, qui entérinent brutalement le deuil de leur grandeur musicale, ils doivent se résoudre à embrasser la carrière enseignante et accepter, en outre, d'y tenir une position subalterne, l'obtention du CA étant fortement corrélée à un apprentissage dans les CNSM. Cette réorientation pédagogique ne peut néanmoins se faire à n'importe quel prix. Parce qu'elle impliquerait un trop grand décalage entre leurs aspirations initiales et leur activité actuelle, et qu'elle acterait ainsi une forme extrême de relégation musicale qu'ils n'ont jamais été préparés à concevoir, la pratique dans un conservatoire déclassé est une situation qu'ils ne peuvent tolérer. Ils vont alors, dès la fin de leur formation musicale, mettre tout en œuvre pour décrocher un emploi dans un établissement intermédiaire, et vont postuler prioritairement dans les CRR.

Cette orientation exclusive vers les CRR révèle en creux le sentiment de déclassement qui guette ces assistants et qui

\subsection{Putting young people to work}

The second model of reassessment of teaching is also found in the CRR under study, in teachers with lower positionsnamely, the assistants. They are holders of a state diploma (DE) and did not graduate from a CNSM. Yet most envisaged, upon reaching adulthood, enrolling in such a prestigious conservatory. Unfortunately, repeated failures at the entrance exam closed the door on elite training, and barred them from accessing the dominant positions in the classical music field. Left to cope with the brutal end of their dreams of musical grandeur, they are forced to embrace a teaching career in a lower position, as obtaining a CA is strongly correlated with studying at a CNSM. This career shift can, however, does not come without its cost. They cannot entertain the prospect of practising at a low-level conservatory because it would be too wide a gap between their initial aspirations and their current activity, and etch in stone an extreme form of music relegation which they were not prepared to consider. Thus, as soon as they complete their musical education, they do everything in their power to secure a job at a mid-level institution, meaning that they mainly apply for work at CRRs.

This overwhelming preference for regional conservatories implicitly points to the sense of downclassing that often threatens these assistants and fuels their traditionalist 
irrigue leurs conceptions pédagogiques traditionalistes ${ }^{29}$. Critiquantlelaxismedespédagogues despetitsconservatoires, ils se posent en garant d'un enseignement d'excellence contribuant à la reproduction du corps musical. Ils s'inscrivent dans une perception rigoriste de l'enseignement musical, en reproduisant scrupuleusement le modèle pédagogique auquel ils ont été confrontés. Il s'agit de transmettre un canon esthétique et une technique classiques, en formant des jeunes musiciens de "qualité », c'est-à-dire qui maîtrisent parfaitement la technique instrumentale classique. Suivant ce but, toutes les tentatives d'atténuation des aspects les plus manifestes de l'inculcation des pratiques ascétiques, considérées comme non conformes au modèle traditionnel, sont rejetées. Le travail personnel quotidien est ainsi exigé dès les débuts à l'instrument, car il constitue, selon eux, la seule façon de progresser. Une telle imposition entraîne alors des défections prématurées d'élèves n'ayant pu ou voulu se conformer à ces exigences. Toutefois, à la différence des enseignants du CRC qui, nous le verrons plus tard, les conçoivent comme un problème, elles ne soulèvent pas l'émoi des assistants du CRR. Si les élèves ne se conforment pas aux exigences de l'enseignement musical, il est normal qu'ils s'en détournent, voire qu'ils soient renvoyés, comme le note Catherine qui enseigne le violon.

29 II est intéressant de relever que l'on observe au sein de cette souspopulation une surreprésentation d'enfants de petits indépendants (agriculteurs, commerçants, artisans), groupes sociaux en déclin et enclins au traditionalisme (Bourdieu 1979). Si la faiblesse numérique de notre population ne permet pas de tirer de conclusion générale, cette observation révèle des dispositions à la reproduction d'un modèle pédagogique traditionnel. concepts of teaching ${ }^{29}$. They readily criticize the laxness of teachers in small conservatories and present themselves as guarantors of a high-level teaching that contributes to the reproduction of the musical corps. Their perception of music education is a rigorist one, which closely mirrors the model to which they have been subjected during their own training. They focus on passing on classical aesthetic canons and techniques, on training "quality" young musicians-meaning musicians with a perfect command of classical instrumental technique. In the pursuit of this ideal, any attempt at playing down the most manifest aspects of the inculcation of ascetic practice will be rejected for failing to comply with the traditional model. They expect daily personal work on the instrument from the very beginning of the musician's education, seeing it as the only way to improve. This causes some students who are unable or unwilling to meet such demands to drop out early. Although we will see that these early defections are perceived as a problem by teachers in the CRC, this is not the case at the CRR. CRR assistants believe that is normal for students who do not meet the demands of music education to give up or even be pushed out-as is related here by Catherine, a violin teacher:

29 It is worth nothing that in this sub-population, we observe that children of lowlevel self-employed workers (farmers, small business owners, craftsmen) are over-represented. These social groups are declining and prone to traditionalism (Bourdieu 2013). Due to the small population of my sample, I cannot draw general conclusions from this, but it suggests that dispositions to reproducing a traditional model of teaching may be at work. 
«Plus ça monte dans les degrés, souvent plus les élèves abandonnent. Parce que c'est difficile. II y en a aussi qui sont peut-être un peu moins doués que certains ou qui ne travaillent pas. C'est sûr que là, en fin déjà de premier cycle, il y a déjà un tri de fait. II y en a qui n'iront pas audelà du premier cycle et même qui n'auront même pas leur examen de fin de premier cycle. Ils seront à la porte malheureusement. Enfin malheureusement, ceci dit on ne peut pas non plus garder tous les élèves. »

L'efficacité de ce modèle traditionnel d'enseignement n'est d'ailleurs pas remise en cause par ces pédagogues. S'il suscite des abandons précoces et génère des exclusions, ce n'est pas selon eux en raison de son inadaptation, mais plutôt à cause de la difficulté accrue de faire accepter des contraintes à des enfants de plus en plus réticents au travail personnel. Ce faisant, ces assistants rejoignent le modèle des catégories sociales en déclin qui, comme le souligne Pierre Bourdieu (1979 : 398-403), manifestent « dans toutes leurs préférences des dispositions régressives qui sont sans doute au principe de leurs inclinations répressives, particulièrement visibles dans leurs réactions à tous les signes de la rupture avec l'ordre ancien, à commencer, bien sûr, par la conduite des jeunes ». Anne-Marie, enseignante de piano, déplore ainsi la faible implication de ses élèves.

« Ils travaillent beaucoup moins de toute façon. Ça, c'est un souci par contre. Et ça, c'est tout à fait général. Parce que justement, c'est un peu une génération de zappeur. Et je reviens au mot "contrainte" du début : quand ils ont trop de contraintes, ils abandonnent. Ils ont un peu moins de "gnac" que nous en avions quand même. Ça, c'est un petit peu le souci quand même. "
"At the higher levels, students drop out more often, because things get hard. There are also those who might be a little bit less gifted than others, or they don't work. Already at the end of the first cycle, you have a selection that's being made. Some of them can't go beyond the first cycle and some won't even pass their first cycle exam, and then unfortunately they'll be out. Well, I say 'unfortunately,' but we can't keep every student, anyway."

These teachers do not question the effectiveness of this traditional model of teaching. They argue that students drop out or are excluded not because the model is inadequate, but because it is increasingly difficult for children who are more and more reluctant to work in their own time to accept its demands. In this sense, the assistants fit the model of members of declining social categories who, in the words of Pierre Bourdieu (2013: 347), manifest "in all their preferences regressive dispositions which are no doubt the source of their repressive inclinations, particularly visible in their reactions to every sign of departure from the old order, not least of course, the behaviour of young people." Anne-Marie, a piano teacher, regrets a lack of commitment from her students:

"They work a lot less, anyway. And that's an issue, and one that's quite widespread. They're a generation who tend to be channel-hoppers. And to come back to the word 'constraint' which I used earlier, when they have too many constraints, they give up. They have less grit than we used to, really. And that's the issue, I have to say." 
Confrontés au prétendu dilettantisme de leurs élèves, les assistants s'acharnent alors à leur inculquer une rigueur de travail. Par ce biais, l'enseignement musical est requalifié dans une perspective plus large de « mise au travail ${ }^{30}$ », d'encadrement de la jeunesse. La pédagogie musicale se pare d'une fonction sociale dépassant le strict cadre instrumental et contribue à forger chez les élèves une discipline et une conscience que le travail est la condition de l'excellence, comme le révèle à nouveau Anne-Marie.

« À partir du moment où il y a la contrainte, notamment quand ils comprennent qu'il y a une contrainte de travail, qu'on travaille tous les jours, alors ça, ça peut être un petit peu déstabilisant pour eux et ils ont un petit peu de mal souvent. Donc bon, c'est notre rôle de leur faire comprendre que c'est un entraînement. Je prends des exemples de la vie courante pour essayer de leur faire comprendre que de travailler tous les jours, c'est hyper important. [...] Je me porte garante de la rigueur et de la qualité. Et c'est presque dommage qu'il n'y ait pas assez d'écoles de musique qui soient dans le même profil que nous, au conservatoire. De toute façon, on n'arrive pas à être un champion de natation si on fait pas cinq entraînements par semaine. On n'arrive pas à être un super. Enfin je veux dire, c'est par le travail qu'on arrive à une qualité. »

\subsection{Transmettre l'amour de la musique}

Le troisième mode de requalification de l'enseignement est représenté par les enseignants du conservatoire le plus modeste : le CRC. Ces enseignants se caractérisent par

30 Pour une autre étude des principes de « mise au travail » de la jeunesse, voir Darmon (2013).
In response to this perceived dilettantism, assistants hammer away at their students to instil a rigorous work ethic in them. In this sense, they reframe music education within a broader effort to put youth to work ${ }^{30}$. Music teaching is given a social function that extends beyond instrumental education and helps to create a sense of discipline among students, and an awareness that hard work is the condition of excellenceagain in the words of Anne-Marie:

"As soon as they've got a constraint, especially when they understand that there's a constraint to work, that you have to work every day, well that can be a little bit unsettling for them, and they struggle with it quite often. So our role is to make them understand that it's training. I take examples from everyday life to try to make them understand that working every day is hugely important... I guarantee rigour and quality. It's almost a shame that there aren't enough music schools that work in the same way as we do at the conservatory. Anyway, you can't be a swimming champion if you don't train five times a week. You can't be one of the greats. I mean, it is with work that you get quality."

\subsection{Channelling the love of music}

The third form of redefinition of teaching is found in the teachers of the most modest conservatory: the CRC. These teachers are characterized by their fit with their function.

30 For another study on how young people are "put to work" (mise au travain) see Darmon (2013). 
leur adéquation avec le poste qu'ils occupent. En effet, ces pédagogues sont peu diplômés (DE ou aucun diplôme) et non passés par le CNSM. Plus encore, l'immense majorité (les $3 / 4$ dans le cas du CRC enquêté), contrairement aux assistants du CRR évoqués précédemment, ne s'est même jamais présentée au concours d'entrée du CNSM. Ayant vu leurs ambitions raisonnées, ils prospectent sur des postes dans des « petits » conservatoires situés dans leur région d'origine qu'ils obtiennent grâce aux relations d'interconnaissance tissées dans le milieu musical local. Ces pédagogues adoptent en outre un mode de perception spécifique de leur pratique pédagogique. Connaissant bien la structuration du système français d'enseignement musical dont ils sont les produits, ils ont conscience que, dans une institution située au bas de la pyramide, une grande partie de leur temps de travail est réservée à des élèves débutants ou peu avancés dans le cursus d'études, les élèves confirmés se dirigeant vers des établissements plus huppés. De cette orientation vers une population débutante découle un rapport particulier à la pédagogie, qui est d'autant plus assumé qu'ils y ont été

préparés.

Dans ce cadre, la problématique de ces enseignants consiste à transmettre un "amour de la musique », expression qui traduit la volonté de conserver le plus longtemps possible leurs jeunes élèves. II s'agit de lutter contre les abandons prématurés et d'amener les enfants à un niveau instrumental correct. Leur préoccupation consiste à former des amateurs de bon niveau qui, à leur sortie du CRC, seront capables de se « débrouiller » musicalement et de « se faire plaisir »
They are less educated (holders of a DE or non-graduates) and have not studied at a CNSM. In fact, the overwhelming majority (around $75 \%$ at the CRC studied) have never taken the CNSM entrance exam. Having had to curb their ambitions, they find positions in low-level conservatories located in their region of origin thanks to their networks in local musical circles. These teachers have a distinct perception of their pedagogic practice. As they are quite familiar with the structure of the French music education system, of which they are products, they are well aware that in lower-level institutions, much of the work is devoted to beginners or students who have not progressed far, as the highest-achieving students attend more prestigious institutions. They have been prepared to deal with these students and it creates a specific relationship to teaching.

In light of this, the main concern of these teachers lies in channelling the "love of music," a phrase that reflects their will to stick with their young students as long as possible. They are intent on making sure that students do not drop out and reach a decent level on their instrument. Their preoccupation consists in training amateurs to good standards, so that once they leave the CRC, they are able to "manage" musically and to "enjoy themselves" when they play. To achieve this, 
en jouant. Pour atteindre cet objectif, tous leurs efforts sont concentrés sur la nécessité de ne pas « dégoûter » les élèves de la pratique instrumentale. Cette ambition amène ces enseignants à adopter un modèle pédagogique particulier. Ils favorisent tout d'abord l'instauration d'une relation privilégiée avec leurs élèves. Essayant de casser la référence scolaire entre le maître et l'élève, ils tentent de développer un rapport de complicité avec l'enfant pour engager celui-ci à s'investir dans la pratique instrumentale. Ils essayent ensuite d'être à l'écoute des envies des enfants dans le choix des morceaux travaillés. Cette attention les conduit régulièrement à s'éloigner du répertoire classique pour leur faire étudier des pièces relevant de la musique contemporaine, du jazz ou de la variété. C'est ce que révèlent les propos de Delphine qui

enseigne le piano.

« J'essaye vraiment de choisir les morceaux en fonction du caractère de l'élève. C'est plus agréable, on va dire, parce qu'après les élèves travailleront plus volontiers un morceau qu'on a choisi en fonction de leur personnalité. Je pense qu'avec le répertoire qu'on a en piano, ça serait quand même malheureux de les obliger à faire des morceaux qu'ils aiment pas, alors qu'il y a plein de choses. [...] Une fois de temps en temps, il y en a un qui m'amène son petit recueil de variétés, même si j'accroche pas sur le chanteur ou la chanteuse, je lui en donne parce que c'est ça qui va les motiver aussi. »

Cette ouverture de leur enseignement à d'autres genres musicaux rejoint d'ailleurs leurs propres pratiques. En effet, à l'inverse des autres pédagogues étudiés précédemment, ces enseignants n'hésitent pas à s'aventurer lors de leurs (rares) prestations d'interprète dans des genres musicaux autres que they focus all their efforts on the need to refrain from "putting students off" playing an instrument. This ambition leads these teachers to adopt a special pedagogic model. First, they strive to create a close relationship with their students. Breaking with the master/pupil dichotomy, they seek to forge a bond with students to make them invest in playing an instrument. Then, they make an effort to listen to the children's wishes when it comes to practice pieces. This leads them to make frequent excursions out of the classical repertoire and into contemporary music, jazz, and pop. This is illustrated by Delphine, a piano teacher:

"I really do try to choose pieces depending on the student's character. It's nicer, let's say, as students are more eager to work on a piece that you've chosen according to their personality. Considering the repertoire we have on the piano, I think it'd be a bit of a shame to force them to do pieces they don't like when there are so many different things to choose from ... Once in a while, one of them'll bring me their pop collection, and even if I'm not into the singer, I'll give them some of their stuff to work on because that's the type of thing that'll motivate them."

This open-minded approach to other music genres reflects these teachers' own practice. Unlike the other previously studied teachers, they have no qualms about venturing beyond the confines of classical music in their (rare) jobs as performers. As their sense of their own limitations makes them 
le classique. Leur « sens des limites musicales » les rendant peu assurés à l'idée de se mesurer au répertoire classique, ils orientent principalement leurs productions instrumentales vers le jazz et les musiques du monde, genres, selon eux, plus « conformes » à leurs capacités instrumentales.

S'ils intègrent d'autres genres musicaux à leur enseignement, les pédagogues du CRC n'en demeurent pas moins attentifs à transmettre le style et le répertoire classiques. Cependant pour maximiser leurs chances de réussir cette transmission, ils l'entreprennent dans une démarche éducative. Plutôt que d'imposer systématiquement des morceaux classiques aux élèves, ils préfèrent s'ouvrir ponctuellement à d'autres genres musicaux correspondant aux goûts des enfants. Les ayant ainsi séduits, ils s'emploient à les sensibiliser « en douceur »

à l'esthétique classique.

Ces stratégies pédagogiques ${ }^{31}$ se doublent d'une moindre exigence concernant le travail personnel. Ce dernier est, bien évidemment, fortement recommandé et surveillé, mais le volume demandé et surtout les conséquences en cas de manquement diffèrent largement de ce qui est édicté dans les CRR. De même, l'obligation de se soumettre à des cours de formation musicale est beaucoup moins stricte ${ }^{32}$. Dès leur

31 On trouve des méthodes d'enseignement relativement similaires chez les professeurs de musique de l'Éducation nationale (Eloy \& Palheta 2008).

32 Dans le système de formation musicale français, les cours d'instrument et de formation musicale (ou solfège) sont distincts. Ces derniers sont considérés par de nombreux élèves comme rébarbatifs et beaucoup cherchent à s'y soustraire. Cela est totalement défendu dans le CRR étudié mais plus toléré au sein du CRC. shy away from tackling the classical repertoire, they mainly turn to jazz and world music in their instrumental output, as they believe those genres to be better suited to their skills.

Although they bring other genres of music into their teaching, the CRC teachers remain keen to channel the classical repertoire and style. However, to make sure that this goes down well, they frame this within an educational approach. They would rather occasionally open up to other genres that suit the young peoples' tastes than systematically force classical pieces on them. Having appealed to them in this way, they then try to gently ease them into the classical aesthetic.

These pedagogic strategies ${ }^{31}$ are combined with a slightly more relaxed approach to individual practice. While the latter is still strongly recommended and monitored, both the amount of work required and the consequences of failing to do the work are far smaller than in CRRs. Likewise, the obligation to attend theory classes is far less strict ${ }^{32}$. While these classes are mandatory up to the end of secondary education in CRRs, children in CRCs can stop attending them

31 Relatively similar teaching methods are observed in music teachers of the mainstream school curricula (Eloy \& Palheta 2008).

32 In the French music education system, instrument and theory classes are separate. Many consider the latter to be dull and seek to avoid attending them. This is completely forbidden at the CRR under study, but tolerated to a greater degree at the $\mathrm{CRC}$. 
entrée en second cycle, les enfants peuvent abandonner cet enseignement théorique, obligatoire jusqu'à la fin du second cycle au CRR. Le rigorisme et le classicisme de l'enseignement des CRR, liés à la position de la structure dans le schéma pyramidal de l'enseignement musical et outils permettant aux enseignants qui y sont les moins diplômés (les assistants) de se distinguer symboliquement de leurs homologues des CRC, sont ici remis en question, en tout cas dans leurs aspects les plus coercitifs.

Ayant conscience du fait que la musique ne représente bien souvent pour leurs élèves qu'un loisir, et qui plus est un loisir parmi d'autres, les enseignants des CRC adaptent leur pédagogie pour faire ressortir les dimensions les plus ludiques de l'apprentissage musical, afin de conserver les enfants le plus longtemps possible. S'ils se soumettent de bonne grâce à une telle appréhension de l'activité enseignante, c'est non seulement du fait de leur intériorisation précoce de la réalité de l'exercice du métier à laquelle ils allaient être confrontés, mais également parce qu'ils peuvent la réinterpréter comme une démarche quasi militante.

En se donnant comme objectif de susciter un « amour de la musique » chez des enfants qui n'y sont pas forcément sujets, afin de produire des instrumentistes amateurs sensibilisés à la musique classique, ils se réclament d'une morale progressiste visant à la démocratisation et à la massification de la pratique musicale ${ }^{33}$. Cette requalification éthique du sens

33 Cette morale n'est pas sans rappeler les principes éthiques dont se réclament les instituteurs et qui se perpétuent, dans ce groupe professionnel, de la fin du XIX ${ }^{e}$ siècle aux années 1980 (Geay 1999). after completing primary education. The rigor and classicism of teaching in CRRs relate to that structure's position in the pyramid scheme of French music education and to the tools allowing its teachers with lower degrees (the assistants) to symbolically distinguish themselves from their counterparts in CRCs. Here, their more overtly coercive aspects are challenged.

Being aware that music is often little more than a hobby among others for their students, the CRC teachers adopt their approach to highlight the most playful dimensions of music education to keep students attending for as long as possible. They are willing to do so not only because they have internalized the realities of their jobs at an early stage, but also because they are able to reinterpret this approach almost as a form of activism.

By setting themselves the goal of ingraining a "love of music" in children who might not initially share this love in order to produce amateur instrumentalists with an awareness of classical music, they claim their adherence to a progressive ethic, which strives towards the democratization and massification of music practice ${ }^{33}$. This ethical reassessment

33 This is reminiscent of the ethical principles of French schoolteachers, which were perpetuated within that professional group from the late nineteenth century to the 1980s (Geay 1999). 
de leur emploi les amène à reconsidérer leur relégation dans l'univers musical. Certes, ils occupent des postes modestes, ne forment pas de professionnels et se contentent d'initier des débutants, concédant en cela une mise en retrait des critères propres au champ musical, mais ils contribuent à la diffusion du savoir instrumental et de l'intérêt pour la musique dans la société et, en cela, ont, d'après eux, une action beaucoup plus déterminante que certains de leurs collègues centrés sur la formation des professionnels ou pris dans l'enseignement rigoriste des CRR. Voici comment Didier, directeur du CRC, rend compte de la mission de son établissement.

« Le travail du conservatoire, c'est quand même un enseignement de masse, c'est de faire faire de la musique à tout le monde. Or le gros problème, c'est que souvent, quand quelqu'un fait de la musique dans une école ou en cours privé, il pratique un instrument et puis, après, il se retrouve tout seul chez lui. Et puis il laisse tomber son instrument, i le range et il n'en joue plus. Donc l'intérêt, c'est d'habituer les enfants à avoir une dynamique de groupe, à jouer à plusieurs, à se faire plaisir. Et puis, surtout, à se montrer, à jouer à droite et à gauche pour que finalement, quand ils vont sortir du conservatoire, ils aient toujours envie de jouer avec d'autres. C'est-à-dire que si on réussit ça, même si on ne sort pas de bons élèves, si les gens qui nous quittent continuent à se revoir entre copains et copines pour faire de la musique, notre mission est réussie. [...] Je me rappellerai toujours une engueulade avec une collègue, prof de piano dans un CRR, qui me disait : "Mais moi j'ai réussi. Tu te rends compte, dans ma carrière, j'ai quand même deux de mes anciens élèves qui sont devenus professeurs." Moi, ça m'énerve beaucoup parce que si on est professeur et qu'on est là pour former des gens qui seront professeurs, of the meaning of their job leads them to reconsider their own relegation in the music world. They may hold low-level positions, train beginners instead of professionals, and as such fall short of the criteria for excellence in the music world, but they contribute to the diffusion of instrumental knowledge and to fostering an interest in music in society. To them, this gives their work much more of an impact than the training of professionals and the rigorist teaching of their colleagues in CRRs. This is how Didier, the director of the CRC under study, explains his institution's mission:

"The conservatory's job is to teach the masses, it's to have everyone learn music, right? But the big problem is that often when someone learns music in a school or in private lessons, they'll practice an instrument and then they'll find themselves alone at home. And they're going to drop their instrument, put it aside and never play anymore. So the point of what we do is to get the kids used to a group dynamic, to playing with others, to enjoying themselves. And mostly to being seen, playing here and there so that ultimately, once they leave the conservatory, they'll still feel like playing with others. If we succeed in doing this, even if we don't turn out good students, if the people who leave us go on to meet up among friends to make music, our work is done. [...] I'll always remember an argument with a colleague, a piano teacher in a CRR, who was telling me: 'I've succeeded, I have. Don't you realize, over the course of my career, l've had two of my former students become teachers.' That really pisses me off, because if we're teachers and we're here to train people who'll in turn be teachers, then that makes no sense. Our goal is to train musicians, professionals or amateurs. Actually, we mostly produce amateurs, thankfully. 
qui formeront des gens qui seront professeurs, on n'en sort pas. Notre but, c'est de former des musiciens qu'ils soient professionnels ou amateurs. Et d'ailleurs, on sort surtout des amateurs et heureusement. Moi je suis plus content quand un élève s'en va d'ici et continue à jouer même tout seul plutôt que quelqu'un qui enseigne. C'est pas le but. »

\section{Conclusion}

L'analyse des déterminants du devenir instrumentiste souligne la prépondérance du système de formation instrumentale dans la naissance et l'entretien de la vocation. Le mythe du “ créateur incréé », vierge de toute forme d'apprentissage formalisé, apparaît ainsi totalement étranger à la fois aux représentations et aux parcours des instrumentistes. Sur ce point, le secteur de la musique classique se distingue d'autres professions artistiques qui postulent une dénégation des apports du système de formation corollaire d'une valorisation de l'inné ${ }^{34}$. Cette singularité de la musique classique s'explique par les particularités de ses modalités d'apprentissage.

La première tient au fait que le système de formation musicale ne rentre pas en contradiction avec la croyance dans le don des artistes. Au contraire, il participe, du fait de son organisation, à la production de la croyance collective dans les qualités innées, dans le talent du musicien. II ne joue pas contre l'héritage familial, mais contribue à la transposition des dispositions héritées en capacités naturelles. Le système de

34 Le rapport à l'institution scolaire des écrivains est ici un exemple édifiant (Sapiro 2007b). Dans le domaine musical, on peut également faire référence au culte de l'autodidacte entretenu chez les musiciens de jazz (Coulangeon 1999)
I'm happier when a student leaves here and continues to play instead of ending up teaching. That's not the point."

\section{Conclusion}

My analysis of the determining factors of instrumentalists' trajectories uncovers the key role played by the music education system in the birth and maintenance of vocations. The myth of the "uncreated creator," untouched by any sort of formal teaching, appears to be completely at odds with the representations and trajectories of instrumentalists. Regarding this, the classical music sector differs from other artistic occupations which are characterized jointly by a denial of the benefits of the education system and an emphasis on innateness ${ }^{34}$. This singularity of classical music derives from its distinct modes of learning.

First, in classical music the education system does not contradict belief in the gift of artists. Instead, due to its organization, it contributes to the production of collective belief in the musician's innate qualities and talent. It does not conflict with family legacies, but facilitates the transposition of inherited dispositions into natural skills. The music education system does not oppose the innate and the acquired; it

34 Writers' relationships to the education system are an edifying example of this (Sapiro 2007b). In the field of music, we may also think of the cult of the selftaught musician that prevails in the jazz world (Coulangeon 1999). 
formation n'oppose pas l'acquis à l'inné, mais, au contraire, postule leur nécessaire coexistence. La seconde particularité réside dans la mise en avant des comportements ascétiques, d'une éthique de travail austère et répétitive dans la vocation instrumentale. Pour les musiciens classiques, le don ne saurait se suffire à lui-même, il convient de l'entretenir et de le développer par un travail acharné. Avoir la vocation, ce n'est pas seulement être doué, c'est aussi faire la preuve de sa dévotion par un engagement total et sacrificiel dans la pratique. La démonstration de cet engagement passe par un apprentissage formalisé et aride, visant la conformation aux canons esthétiques et aux exigences techniques relayés par les conservatoires, qui se chargent d'inculquer les pratiques ascétiques et de vérifier l'investissement du jeune instrumentiste. La soumission à une éthique de travail, signe de l'adhésion à la valeur des enjeux et à la tradition musicale, est donc à la fois produite et contrôlée par le système de formation, qui s'arroge ainsi le monopole de la fabrique d'instrumentistes adhérant à l'illusio du champ de la musique

classique.

Cette adhésion explique que, même privés des rétributions symboliques associées aux positions dominantes, les enseignants des conservatoires trouvent des formes de réenchantement de leur vocation dans la réinterprétation de la pratique pédagogique. Ces formes diffèrent cependant selon leurs trajectoires et leurs positions, les mieux dotés pouvant se « raccrocher » au mythe de l'art pur, tandis que les moins pourvus en capital spécifique s'orientent vers des requalifications plus sociales opposant visions postulates their necessary coexistence. Secondly, it nurtures ascetic behaviours and an austere, repetitive work ethic in the vocation of being a professional musician. For classical musicians, the gift itself is not enough: one must cultivate it and develop it through hard work. Having a vocation means not only being gifted, but also proving one's devotion by fully committing to playing an instrument to the point of selfsacrifice. Demonstrating this commitment involves a dull, formalized learning process focused on conforming to the aesthetic canons and technical demands of conservatories, which inculcate aesthetic practices and monitor the commitment of young instrumentalists. Submission to a work ethic, a sign of deference to the value of the stakes involved and to musical tradition, is both produced and monitored by the music education system, which holds a monopoly on the production of instrumentalists who are dedicated to the illusio of the classical music field.

This dedication explains what motivates teachers to find forms of re-enchantment of their vocation by reinterpreting their pedagogic practice even when they are deprived of the symbolic rewards associated with the dominant positions. However, these forms differ according to their trajectory and position. Those best endowed in capital can hold on to the myth of art for art's sake, whereas the less endowed turn to more social redefinitions of their work-traditionalist approaches focused on putting young people to work, or 
traditionaliste d'encadrement de la jeunesse et progressiste de démocratisation culturelle.

Adrien Pégourdie

Université de Limoges, GRESCO http://gresco.labo.univ-poitiers.fr/

\section{Références bibliographiques}

ALFORD Robert \& SZANTO Andras (1995). «Orphée blessé. L'expérience de la douleur dans le monde professionnel du piano ». Actes de la recherche en sciences sociales, $110: 56-65$.

Augustins Georges (1991). "Le don chez les musiciens ". In SEGALEN Martine (dir.), Jeux de famille. Paris, Presses du CNRS : 99-113.

BERTRAND Julien (2009). « Entre "passion” et incertitude : la socialisation au métier de footballeur professionnel ». Sociologie du travail, 51(3) : 361-378.

BouRdieu Pierre (1972). Esquisse d'une théorie de la pratique, Genève, Droz.

BOURDIEU Pierre (1979). La Distinction. Critique sociale du jugement. Paris, Minuit.

BOURDIEU Pierre (1982). «Les rites comme actes d'institution ». Actes de la recherche en sciences sociales, $43: 58-63$.

BouRdieu Pierre (1994). Raisons pratiques. Sur la théorie de l'action. Paris, Seuil.

BuRLAND Karen \& DAVIDSON Jane (2004). « Rôle des parents dans le développement du musicien classique professionnel ». Staps, 64 : 89107 progressive implementations of a cultural democratization ideal.

Adrien Pégourdie Université de Limoges, GRESCO http://gresco.labo.univ-poitiers.fr/

\section{References}

Alford Robert \& SzAnto Andras (1995). "Orphée blessé. L'expérience de la douleur dans le monde professionnel du piano." Actes de la recherche en sciences sociales, 110: 56-65.

Augustins Georges (1991). "Le don chez les musiciens." In SEgaleN Martine (ed.), Jeux de famille. Paris, Presses du CNRS: 99-113.

BERTRAND Julien (2009). "Entre 'passion' et incertitude: la socialisation au métier de footballeur professionnel." Sociologie du travail, 51(3): 361-378.

BOURDIEU Pierre (1977). Outline of a Theory of Practice. English translation by Richard Nice. Cambridge, Cambridge University Press.

BOURDIEU Pierre (1982). "Les rites comme actes d'institution." Actes de la recherche en sciences sociales, 43: 58-63.

Bourdieu Pierre (2013). Distinction. A Social Critique of a Judgement of Taste. English translation by Richard Nice. London/New York, Routledge.

Bourdieu Pierre (1998). Practical Reason. On the Theory of Action. English translation by Randall Johnson. Stanford, Palo Alto, Stanford University Press.

BURLAND Karen \& DAVIDSON Jane (2004). "Rôle des parents dans le développement du musicien classique professionnel." Staps, 64: 89-107. 
CoulAngeOn Philippe (1999). «Les musiciens de jazz : les chemins de la professionnalisation ». Genèses, 36 : 54-68.

Coulangeon Philippe \& RAVET Hyacinthe (2003). « La division sexuelle du travail chez les musiciens français ». Sociologie du travail, 45(3) : 361384.

CoulAngeon Philippe (2004). Les Musiciens interprètes en France. Portrait d'une profession. Paris, La Documentation française.

DARMON Muriel (2013). Classes préparatoires. La fabrique d'une jeunesse dominante. Paris, La Découverte.

Defrance Jacques (1987). L'Excellence corporelle. La formation des activités physiques et sportives modernes : 1770-1914. Rennes, Presses Universitaires de Rennes.

DuBoIs Vincent (2013). La Culture comme vocation. Paris, Raisons d'agir.

DURKHEIM Émile (1988) [1895]. Les Règles de la méthode sociologique. Paris, Flammarion.

DURKHEIM Émile (2008) [1912]. Les Formes élémentaires de la vie religieuse. Paris, Presses Universitaires de France.

EliAs Norbert (1991). Mozart. Sociologie d'un génie. Traduit de l'allemand par Jeanne Etoré et Bernard Lortholary. Paris, Seuil.

ELOY Florence \& PALHETA Ugo (2008). « Cultures juvéniles et enseignement musical au collège ». Revue Française de pédagogie, 163 : 39-50.

FAURE Sylvia (2000). Apprendre par corps. Socio-anthropologie des techniques de danse. Paris, La Dispute.
CoULANGEON Philippe (1999). "Les musiciens de jazz: les chemins de la professionnalisation." Genèses, 36: 54-68.

Coulangeon Philippe \& Ravet Hyacinthe (2003). "La division sexuelle du travail chez les musiciens français." Sociologie du travail, 45(3): 361-384.

Coulangeon Philippe (2004). Les Musiciens interprètes en France. Portrait d'une profession. Paris, La Documentation française.

DARMON Muriel (2013). Classes préparatoires. La fabrique d'une jeunesse dominante. Paris, La Découverte.

Defrance Jacques (1987). L'Excellence corporelle. La formation des activités physiques et sportives modernes: 1770-1914. Rennes, Presses Universitaires de Rennes.

DuBoIs Vincent (2016). Culture as a Vocation. English translation by JeanYves Bart. Londres, Routledge.

DURKHEIM Émile (1982). Rules of Sociological Methods. English translation by W. D. Halls. New York, Free Press.

DURKHEIM Émile (2008) [1915]. The Elementary Forms of Religious Life. English translation by Carol Cosman $\left(1^{\text {st }}\right.$ translation by Joseph Ward Swain, 1915). Oxford, Oxford University Press.

Elias Norbert (1993). Mozart. Portrait of a Genius. English translation by Edmund Jephcott. Berkeley, University of California Press.

ElOY Florence \& PALHETA Ugo (2008). "Cultures juvéniles et enseignement musical au collège." Revue Française de pédagogie, 163: 39-50.

FAURE Sylvia (2000). Apprendre par corps. Socio-anthropologie des techniques de danse. Paris, La Dispute. 
GeAY Bertrand (1999). Profession : Instituteurs. Mémoire politique et action syndicale. Paris, Seuil.

Grignon Claude (1971). L'Ordre des choses. Les fonctions sociales de l'enseignement technique. Paris, Minuit.

HEINICH Nathalie (2005). L'Élite artiste. Excellence et singularité en régime démocratique. Paris, Gallimard.

Jounin Nicolas (2014). Voyage de classes. Des étudiants de Seine-SaintDenis enquêtent dans les beaux quartiers. Paris, La Découverte.

KATZ Serge (2006). «Quand savoir faire c'est savoir être. L'élève comédien à l'épreuve de la perception professionnelle de son corps ». In

MAUGER Gérard (dir.). L'Accès à la vie d'artiste. Sélection et consécration artistiques. Bellecombe-en-Bauges, Le Croquant : 49-70.

KRIS Ernst \& Kurz Otto (1987) [1934]. L'Image de l'artiste : légende, mythe et magie [Die Legende vom Künstler : Ein historischer Versuch, Vienne, Krystall Verlag]. Traduit de l'anglais par Michèle Hechter. Marseille, Rivages.

LAILLIER Joël (2011). "Des familles face à la vocation. Les ressorts de l'investissement des parents des petits rats de l'Opéra ". Sociétés contemporaines, $82: 59-83$

LeFĖVRE Nicolas (2010). «Construction sociale du don et de la vocation de cycliste ». Sociétés contemporaines, $80:$ 47-71.

LeHMANN Bernard (2005). L'Orchestre dans tous ses éclats. Ethnographie des formations symphoniques. Paris, La Découverte.
GEAY Bertrand (1999). Profession: Instituteurs. Mémoire politique et action syndicale. Paris, Seuil.

Grignon Claude (1971). L'Ordre des choses. Les fonctions sociales de l'enseignement technique. Paris, Minuit.

HEINICH Nathalie (2005). L'Élite artiste. Excellence et singularité en régime démocratique. Paris, Gallimard.

Jounin Nicolas (2014). Voyage de classes. Des étudiants de Seine-SaintDenis enquêtent dans les beaux quartiers. Paris, La Découverte.

KATZ Serge (2006). "Quand savoir faire c'est savoir être. L'élève comédien à l'épreuve de la perception professionnelle de son corps." In

MAUgeR Gérard (ed.), L'Accès à la vie d'artiste. Sélection et consécration artistiques. Bellecombe-en-Bauges, Le Croquant: 49-70.

KRIS Ernst \& KuRz Otto (1979) [1934]. Legend, Myth, and Magic in the Image of the Artist: A Historical Experiment [Die Legende vom Künstler: Ein historischer Versuch, Vienne, Krystall Verlag]. English translation from German by Alastair Laing \& Lottie M. Newman. Yale, Yale University Press.

LAILLIER Joël (2011). "Des familles face à la vocation. Les ressorts de l'investissement des parents des petits rats de l'Opéra." Sociétés contemporaines, 82: 59-83.

Lefèvre Nicolas (2010). "Construction sociale du don et de la vocation de cycliste." Sociétés contemporaines, 80: 47-71.

LeHMANn Bernard (2005). L'Orchestre dans tous ses éclats. Ethnographie des formations symphoniques. Paris, La Découverte. 
MAuss Marcel (2004) [1950]. Sociologie et anthropologie. Paris, Presses Universitaires de France.

MENGER Pierre-Michel (2002). « Le génie et sa sociologie. Controverses interprétatives sur le cas de Beethoven ». Annales. Histoire, Sciences Sociales, 57(4) : 967-999.

MenGer Pierre-Michel (2004). « Talent et réputation. Ce que valent les analyses sociologiques de la valeur de l'artiste, ce qui prévaut dans la sociologie ". In BLANC Alain \& PESSIN Alain (dir.). L'Art du terrain. Mélanges offerts à Howard S. Becker. Paris, L'Harmattan : 104-161.

MORINIĖRE Thomas (2007). « Les petites voies de la chanson de variétés. La révélation du charisme du chant et la démocratisation de la vocation d'interprète ». Actes de la recherche en sciences sociales, 168 : 68-81.

Orange Sophie (2013). L'Autre enseignement supérieur. Les BTS et la gestion des aspirations scolaires. Paris, Presses Universitaires de France.

PÉgourdie Adrien (2013). Les Provinces de la musique. Pratiques professionnelles, trajectoires et rapport au métier des instrumentistes classiques limougeauds (thèse de doctorat en sociologie). Limoges, Université de Limoges.

PÉGOURDIE Adrien (2015a). “ L'instrumentalisation” des carrières musicales. Division sociale du travail, inégalités d'accès à l'emploi et renversement des hiérarchies dans les conservatoires de musique ». Sociologie, 6(4) : 321-338.

PÉGOURDIE Adrien (2015b). « Les voies sociales de la consécration musicale : inégalités instrumentales de reconnaissance et gestion de l'insuccès en musique classique ». Sociologie et sociétés, 47(2) : 137161.
Mauss Marcel (2011). The Gift. Forms and Functions of Exchange in Archaic Societies. English translation by lan Cunnison. London, Cohen \& West.

Menger Pierre-Michel (2002). "Le génie et sa sociologie. Controverses interprétatives sur le cas de Beethoven." Annales. Histoire, Sciences Sociales, 57(4): 967-999.

Menger Pierre-Michel (2004). "Talent et réputation. Ce que valent les analyses sociologiques de la valeur de l'artiste, ce qui prévaut dans la sociologie." In BLANC Alain \& PESSIN Alain (eds.), L'Art du terrain. Mélanges offerts à Howard S. Becker. Paris, L'Harmattan: 104-161.

MORINIĖRE Thomas (2007). "Les petites voies de la chanson de variétés. La révélation du charisme du chant et la démocratisation de la vocation d'interprète." Actes de la recherche en sciences sociales, 168: 68-81.

Orange Sophie (2013). L'Autre enseignement supérieur. Les BTS et la gestion des aspirations scolaires. Paris, Presses Universitaires de France.

PéGourdie Adrien (2013). Les Provinces de la musique. Pratiques professionnelles, trajectoires et rapport au métier des instrumentistes classiques limougeauds (PhD dissertation, Sociology). Limoges, Université de Limoges.

PÉGOURDIEAdrien (2015a). “L'instrumentalisation' des carrières musicales. Division sociale du travail, inégalités d'accès à l'emploi et renversement des hiérarchies dans les conservatoires de musique." Sociologie, 6(4): 321-338.

PÉGourdie Adrien (2015b). "Les voies sociales de la consécration musicale: inégalités instrumentales de reconnaissance et gestion de l'insuccès en musique classique." Sociologie et sociétés, 47(2): 137-161. 
RAVET Hyacinthe (2007). «Devenir clarinettiste. Carrières féminines en milieu masculin ». Actes de la recherche en sciences sociales, $168: 50-$ 67.

SAPIRO Gisèle (2007a). «La vocation artistique entre don et don de soi ». Actes de la recherche en sciences sociales, $168: 4-11$.

SAPIRO Gisèle (2007b). « "Je n'ai jamais appris à écrire”. Les conditions de formation de la vocation d'écrivain ". Actes de la recherche en sciences sociales, $168: 12-33$.

SCHEPENS Eddy (1995). Les Anciens Étudiants des Conservatoires nationaux supérieurs de musique de Paris et de Lyon de 1979 à 1990. Paris, Ministère de la Culture, DEP.

SCHOtTÉ Manuel (2012). La Construction du «talent ». Sociologie de la domination des coureurs marocains. Paris, Raisons d'agir.

SchwarTz Olivier (1990). Le Monde privé des ouvriers. Hommes et femmes du Nord. Paris, Presses Universitaires de France.

SORIGNET Pierre-Emmanuel (2004). "Sortir d'un métier à vocation : le cas des danseurs contemporains ». Sociétés contemporaines, $56: 111-132$.

SORIGNET Pierre-Emmanuel (2012). Danser. Enquête dans les coulisses d'une vocation. Paris, La Découverte.

SUAUd Charles (1974). "Contribution à une sociologie de la vocation : destin religieux et projet scolaire ». Revue française de sociologie, 15(1) : 75-111.

SuAUd Charles (1978). La Vocation. Conversion et reconversion des prêtres ruraux. Paris, Minuit.
RAVET Hyacinthe (2007). "Devenir clarinettiste. Carrières féminines en milieu masculin." Actes de la recherche en sciences sociales, 168: 50-67.

SAPIRO Gisèle (2007a). "La vocation artistique entre don et don de soi." Actes de la recherche en sciences sociales, 168: 4-11.

SAPIRO Gisèle (2007b). "Je n'ai jamais appris à écrire.' Les conditions de formation de la vocation d'écrivain." Actes de la recherche en sciences sociales, 168: 12-33.

SCHEPENS Eddy (1995). Les Anciens Étudiants des Conservatoires nationaux supérieurs de musique de Paris et de Lyon de 1979 à 1990. Paris, Ministère de la Culture, DEP.

SCHOTTÉ Manuel (2012). La Construction du "talent." Sociologie de la domination des coureurs marocains. Paris, Raisons d'agir.

Schwartz Olivier (1990). Le Monde privé des ouvriers. Hommes et femmes du Nord. Paris, Presses Universitaires de France.

SORIGNET Pierre-Emmanuel (2004). "Sortir d'un métier à vocation: le cas des danseurs contemporains." Sociétés contemporaines, 56: 111-132.

SORIGNET Pierre-Emmanuel (2012). Danser. Enquête dans les coulisses d'une vocation. Paris, La Découverte.

SuAUD Charles (1974). "Contribution à une sociologie de la vocation: destin religieux et projet scolaire." Revue française de sociologie, 15(1): 75-111.

SuAud Charles (1978). La Vocation. Conversion et reconversion des prêtres ruraux. Paris, Minuit. 
WACQUANT Loïc (2002). Corps et âme. Carnets ethnographiques d'un apprenti boxeur. Marseille, Agone.

WAGNER Izabela (2004). « La formation des violonistes virtuoses : les réseaux de soutien ». Sociétés contemporaines, 56 : 133-163.

Weber Max (2000) [1904, 1905]. L'Éthique protestante et l'esprit du capitalisme [Die protestantische Ethik und der Geist des Kapitalismus, Archiv für Sozialwissenschaft und Sozialpolitik]. Traduit de l'allemand par Isabelle Kalinowski (première traduction en français par Jacques Chavy, Plon, 1964). Paris, Flammarion.

Weber Max (1995) [1921]. Économie et société, tome 1, Les Catégories de la sociologie [Wirtschaft und Gesellschaft, tome 1, Soziologische Kategorienlehre]. Traduit de l'allemand par Julien Freund. Paris, Plon.

ZARCA Bernard (2009). « L'ethos professionnel des mathématiciens ». Revue française de sociologie, 50(2) : 351-384.

ZUNIGO Xavier (2010). « Le deuil des grands métiers. Projet professionnel et renforcement du sens des limites dans les institutions d'insertion ». Actes de la recherche en sciences sociales, $184: 58-71$.
WACQUANT Loïc (2003). Body and Soul: Notebooks of an Apprentice Boxer. English translation by the author. Oxford, Oxford University Press.

WAGNER Izabela (2004). "La formation des violonistes virtuoses: les réseaux de soutien." Sociétés contemporaines, 56: 133-163.

Weber Max (2010) [1904, 1905]. The Protestant Ethic and the Spirit of Capitalism [Die protestantische Ethik und der Geist des Kapitalismus, Archiv für Sozialwissenschaft und Sozialpolitik]. English translation from German by Stephen Kalberg (first translated in English by Talcott Parsons, London, George Allen \& Unwin Ltd., 1930). Oxford, Oxford University Press.

Weber Max (2013) [1921]. Economy and Society. English translation by Ephraim Fischoff et al. Berkeley, University of California Press ( $1^{\text {st }}$ ed. 1968).

ZARCA Bernard (2009). "L'ethos professionnel des mathématiciens." Revue française de sociologie, 50(2): 351-384.

Zunigo Xavier (2010). "Le deuil des grands métiers. Projet professionne et renforcement du sens des limites dans les institutions d'insertion." Actes de la recherche en sciences sociales, 184: 58-71. 